\title{
ANALIZA I OCENA POLSKIEGO PAŃSTWOWEGO RYBOŁÓWSTWA KUTROWEGO NA MORZU BAŁTYCKIM W LATACH 1971-2001 FLOTA, POŁOWY, WYNIKI
}

\begin{abstract}
Streszczenie. Celem artykułu jest prezentacja polskiego, państwowego rybołówstwa na Morzu Bałtyckim w latach 1971-2001. W okresie tym doszło do znaczących przemian badanej branży, która obok gruntownej modernizacji zakończonej w praktyce dopiero w 1992 r. cechowała się niezwykle zmiennymi wynikami połowowymi. Ostatecznie rozpoczęcie w 1989 r. przemian prywatyzacyjnych spowodowało ogromną marginalizację rybołówstwa zmieniając na zawsze jego strukturę własności. Zmiany te dotknęły głównie państwowe kombinaty połowowe oraz spółdzielnie tworzące swoiste filary państwowego rybołówstwa na Morzu Bałtyckim. W pierwszej części artykułu zaprezentowano zagadnienia związane z liczebnością floty państwowych przedsiębiorstw i spółdzielni, przeprowadzone modernizacje oraz zbadano struktury flot uwzględniając uśredniona moc [KM] oraz wyporność [GT]. Część druga prezentuje zagadnienia związane z połowami. Do najważniejszych czynników poddanych analizie należy włączyć łączny wolumen pozyskania surowca, podział wyników między kombinaty i spółdzielnie, udział poszczególnych przedsiębiorstw państwowych w połowach oraz uśrednione rezultaty uzyskiwane przez poszczególne klasy jednostek. Ostatnia cześć omawia zagadnienia związane z uśrednionymi wynikami połowowymi $\mathrm{w}$ tonach $\mathrm{w}$ przeliczeniu na moc [KM] oraz $\mathrm{w}$ tonach na wyporność [GT]. Dodatkowym uzupełnieniem jest wskazanie uśrednionych wyników przypadających na ogół zatrudnienia w badanych podmiotach oraz w przeliczeniu na rybaków.
\end{abstract}

Słowa kluczowe: rybołówstwo bałtyckie, lota kutrowa, wyniki, flota państwowa, kutry. 


\section{Wprowadzenie}

$\mathrm{P}$ olskie rybołówstwo bałtyckie doby PRL i późniejszej transformacji było jedną z gałęzi gospodarki najpierw centralnie planowanej, a później rynkowej. Obok wymiernych efektów ekonomicznych w postaci zaopatrzenia rynku w „białko pochodzenia niezwierzęcego” wpasowywało się $\mathrm{w}$ tradycje regionu północnej Polski ${ }^{1}$. Dodatkowo podkreślało pozycję PRL-u, jako państwa eksploatującego zasoby morza, a więc swoistego gospodarza przyznanych obszarów nadmorskich. Później okazało się, że takie propagandowe podejście, wielokrotnie pozbawione zasad realnego rachunku ekonomicznego, miało efekty $\mathrm{w}$ postaci masowych zwolnień i likwidacji poszczególnych podmiotów.

W prezentowanym na łamach niniejszego artykułu okresie na polskie rybołówstwo bałtyckie do 1989 r. składało się łącznie pięć Przedsiębiorstw Połowów i Usług Rybackich (PPiUR), zmienna liczba Spółdzielni Pracy Rybołówstwa Morskiego (SPRM) oraz funkcjonujący w ograniczonym stopniu rybacy indywidualni ${ }^{2}$. 0 ile dwa pierwsze rodzaje podmiotów, działające

${ }^{1}$ Określenie stosowano, jako próbę podtrzymania funkcjonowania rybołówstwa w skrajnie pogarszających się warunkach ekonomicznych. Podjęto działania mające na celu uzasadnienie braku wystarczającej ilości białka zwierzęcego na rynku. Mimo widocznego spadku zasobów oraz rosnących kosztów utrzymania floty, cały czas realizowano połowy, które w wielu przypadkach nie miały racjonalnego uzasadnienia. Mylnie wykazywano, że cena wytworzenia $1 \mathrm{~kg}$ biała zwierzęcego była wyższa niż cena uzyskania $1 \mathrm{~kg}$ białka pochodzenia rybnego. Przykładem było ukierunkowanie floty bałtyckiej na uzyskiwanie dorsza, którego biomasa została przetrzebiona i finalnie uszczuplona. Nie koncentrowano się natomiast na rybach pelagicznych (szprot, śledź) uzasadniając to brakiem popytu rynkowego i niskimi cenami skupu. Jednym z argumentów były również preferencje zakupowe Polaków, którzy nie pożądali produktów z ryb pelagicznych (Archiwum Zakładu Ekonomiki Rybackiej MIR (dalej: AEK MIR), Z. Polański, Sytuacja polskiego rybołówstwa na Bałtyku. Nakład połowowy, połowy, efekty, limity, Gdynia 1991, [maszynopis niepublikowany], s. 1; AEK MIR, idem, Z. Russek, Propozycje i warunki przekształceń własnościowych w polskiej gospodarce rybnej /projekt wstępny/, Gdynia 1990, [maszynopis niepublikowany], s. 3-4).

${ }^{2}$ Według stanu na 1989 r. polskie rybołówstwo bałtyckie doby gospodarki centralnie planowanej tworzyły następujące kombinaty: PPiUR „Koga” w Helu, PPiUR „Szkuner” we Władysławowie, PPiUR „Korab” w Ustce, PPiUR „Kuter” w Darłowie, PPiUR „Barka” w Kołobrzegu. Wszystkie pięć przedsiębiorstw eksploatowało wyłącznie kutry. W ramach spółdzielni funkcjonowały: SPRM „Im. M. Kopernika” we Fromborku, SPRM „Zalew” w Tolkmicku, SPRM „Żagiel” w Stegnie, SPRM „Wyzwolenie” w Świbnie (K), SPRM „Jedność Rybacka” w Gdańsku (K), SPRM „Gryf” we Władysławowie (K), SPRM „Rybmor” w Łebie (K), SPRM „Łosoś” w Ustce (K), SPRM „Ławica” w Darłowie (K), SPRM „Bałtyk” w Kołobrzegu (K), SPRM „Rega” w Mrzeżynie, SPRM „Belona” w Dziwnowie (K), SPRM „Certa” w Szczecinie. Literą „K” oznaczono podmioty eksploatujące w swoich flotach kutry. Dodatkowo łowiska Morza Bałtyckiego wykorzystywała flota znajdująca się w posiadaniu rybaków indywidualnych, nie jest ona jednak opisywana w niniejszym artykule ze względu na wyłącznie prywatną strukturę własności, Gospodarka rybna w latach 1986-1989, red. J. Grzenia, M. Gustowska, T. Jasińska i inni, Gdynia 1991, tab. 48. 
w oparciu o zasady gospodarki centralnie planowanej, były kalką systemową wzorowaną na ZSRS, tak podmioty indywidualne stanowiły dopuszczenie prywatnego kapitału. Nad całością gospodarki rybnej czuwało Zjednoczenie Przedsiębiorstw Gospodarki Rybnej (ZGR) z siedzibą w Szczecinie. Ten kombinatowo-rozdzielczy system posiadał szereg patologii, do których należało zaliczyć brak realnego rachunku zysków i strat, przerost zatrudnienia oraz brak nastawienia na innowacyjność i marketing ${ }^{3}$.

W ramach gospodarki socjalistycznej wszystkie wytyczne były tworzone na szczeblu centralnym, gdzie wielokrotnie popełniano szereg błędnych decyzji. Należały do nich m.in. kolejne modernizacje poszczególnych podmiotów, prowadzone wdrożenia nowych kutrów, które nie były rozmieszczane równomiernie oraz zmiany natury kadrowej. W momencie zderzenia z wolnym, samoregulującym się rynkiem przedsiębiorstwa i spółdzielnie były pozbawione szans na przetrwanie. Znajdująca się w ich posiadaniu flota kutrowa została $w$ ramach procesu prywatyzacyjnego sprzedana lub oddana $\mathrm{w}$ leasing rybakom indywidualnym. Zdarzenia te umożliwiły wybór cezur czasowych, gdzie pierwsza z nich wskazuje rozpoczęcie wdrażania nowych jednostek burtowych typu B-25s/A, a druga koniec transformacji własności we flocie kutrowej" .

\section{Państwowa flota kutrowa na Morzu Bałtyckim w latach 1971-2001}

Przedmiotem analizy prezentowanej na rysunku 1 jest łączna liczba kutrów eksploatowanych przez państwowe przedsiębiorstwa. Ważne jest wskazanie armatorów opisywanych jednostek. W pierwszej kolejności należy do nich włączyć kombinaty połowowe. Na przestrzeni lat 1971-1989 było to pięć PPiUR, które eksploatowały w ramach swoich flot wyłącznie kutry.

${ }^{3}$ AEK MIR, E. Kuzebski, Ocena efektów ekonomicznych zmian strukturalnych i własnościowych w państwowych przedsiębiorstwach połowowych, Gdynia 1996, [maszynopis niepublikowany], s. 10-11.

${ }^{4} \mathrm{~W}$ początkowym etapie odtwarzania polskiej floty kutrowej na Morzu Bałtyckim po $1945 \mathrm{r}$., masowo wprowadzano do służby jednostki burtowe. Najpierw konstrukcji drewnianej, budowane w kilku seriach, stopniowo wzmacniały potencjał floty. W okresie późniejszym do służby w państwowym rybołówstwie wprowadzano jednostki konstrukcji kompozytowej (kadłub drewniany ze stalowymi wzmocnieniami). Pod koniec lat pięćdziesiątych XX w. do służby weszły stalowe burtowce typu B-25s, które zmieniły obraz polskiego rybołówstwa na Morzu Bałtyckim. Należy uznać je za I falę modernizacji floty kutrowej. Finalną ewolucją omawianej klasy jednostek były przeznaczone dla państwowych przedsiębiorstw kutry typu B-25s/A (ewolucja konstrukcyjna typu B-25s) oraz burtowce KB-21 oraz KŁ-21 przeznaczone dla SPRM. Jednostki typu B-25s/A stanowiły II falę modernizacji floty. Nazwa jednostek wywodzi się od metody wydawania i wybierania włoków trałowych, która realizowana jest przez burtę. Całość operacji manipulacyjnych odbywa się na pokładzie znajdującym się na śródokręciu jednostki (R. Leszczyński, Tragedie rybackiego morza, t. 1, Gdynia-Gdańsk 2005, s. 3). 
Drugim trzonem państwowej floty na Morzu Bałtyckim była zmienna liczba spółdzielni zrzeszona w ramach SPRM ${ }^{5}$. W szczytowym momencie przypadającym na 1973 r. w służbie znajdowała się rekordowa liczba 357 kutrów ${ }^{6}$. W okresie późniejszym wraz z postępującą modernizacją floty, która polegała na wprowadzeniu do linii, burtowców typów B-25s/A, KB-21, KŁ-21, a także trawlerów rufowych typów B-410 oraz B-403, liczba jednostek ulegała zmniejszeniu ${ }^{7}$. Niewielki wzrost zanotowano w 1980 r., jednakże był on związany z zaawansowaniem prac modernizacyjnych, które zbiegły się ze spowolnieniem $w$ kasacji przestarzałych jednostek. Zgodnie z informacjami zamieszczonymi na rys. 1 . wielkość floty w prezentowanym okresie malała, osiągając najniższy poziom w $1989 \mathrm{r}^{8}$

${ }^{5}$ Liczba SPRM eksploatujących kutry na przestrzeni badanego okresu wskutek reorganizacji zmieniała się. W latach 1971-1975 w prezentowanej kategorii znajdowało się 7 podmiotów. W latach 1976-1981 - 6 podmiotów. Od 1982 r. ich liczba wzrosła do 8 i była niezmienna do $1989 \mathrm{r}$.

${ }^{6}$ Morska gospodarka rybna PRL 1945-1985, red. W. Borowski, P. Bykowski, D. Dutkiewicz i inni, Gdynia 1989, s. 15; Gospodarka rybna w latach 1973-1975. Materiały do badań, „Studia i Materiały MIR, Seria E, Nr 35, red. R. Maj, D. Dutkiewicz, H. Ganowiak i inni, Gdynia 1978, s. 110-111.

7 W efekcie prowadzonych modernizacji floty eksploatowanej przez kombinaty wycofywano ze służby głównie starsze jednostki posiadające kadłuby kompozytowe (typ: B-12, B-25). Był to proces naturalny, ponieważ likwidowano kutry uznane za wyeksploatowane w momencie wycofania. Wprowadzone do służby trawlery rufowe cechowały się długimi pokładami roboczymi zlokalizowanymi na rufie jednostki, gdzie wykonuje się całość prac manipulacyjnych. Pierwsze konstrukcje trawlerów rufowych wyłączając typ TR-27, posiadały ładownie na dziobie (B-410 oraz B-403). Późniejsze ewolucje konstrukcji (typy: B-280 oraz TMC-001) posiadały ładownie w środkowej sekcji jednostki (Archiwum Firmowe Przedsiębiorstwa Połowów i Usług Rybackich „Koga” w Helu (dalej AF PPiUR „Koga”), Biuletyn jubileuszowy 1989, Hel 1989, s. 19.)

${ }^{8}$ W 1971 r. Przedsiębiorstwa Połowów i Usług Rybackich eksploatowały łącznie 226 kutrów, 1972 r. - 232 kutry, 1973 r. - 242 kutry, 1974 r. - 240 kutrów, 1975 r. - 238 kutrów, 1976 r. - 235 kutrów, 1977 r. - 232 kutry, 1978 r. - 227 kutrów, 1979 r. - 226 kutrów, 1980 r. - 228 kutrów, 1981 r. - 221 kutrów, 1982 r. - 210 kutrów, 1983 r. - 195 kutrów, 1984 r. - 191 kutrów, 1985 r. - 189 kutrów, 1986 r. - 177 kutrów, 1987 r. - 171 kutrów, 1988 r. - 163 kutry, 1989 r. - 151 kutrów. W 1971 r. Spółdzielnie Pracy Rybołówstwa Morskiego eksploatowały łącznie 116 kutrów, 1972 r. - 116 kutrów, 1973 r. - 115 kutrów, 1974 r. - 115 kutrów, 1975 r. - 114 kutrów, 1976 r. - 115 kutrów, 1977 r. - 115 kutrów, 1978 r. - 117 kutrów, 1979 r. - 117 kutrów, 1980 r. - 117 kutrów, 1981 r. - 116 kutrów, 1982 r. - 116 kutrów, 1983 r. - 112 kutrów, 1984 r. - 110 kutrów, 1985 r. - 107 kutrów, 1986 r. - 99 kutrów, 1987 r. - 92 kutry, 1988 r. - 91 kutrów, 1989 r. - 87 kutrów (Gospodarka rybna w latach 1971-1973. Materiały do badań, „Studia i Materiały MIR”, Seria E, nr 29, red. R. Maj, K. Siudziński, J. Popiel i inni, Gdynia 1975, s. 100-101; Gospodarka rybna w latach 1972-1974. Materiały do badań, „Studia i Materiały MIR", Seria E, nr 31, red. R. Maj, K. Siudziński, J. Popiel i inni, Gdynia 1976, s. 90-91; Gospodarka rybna w latach 1973-1975..., s. 110-111; Gospodarka rybna w latach 1974-1976. Materiały do badań, „Studia i Materiały MIR”, Seria E, nr 40, red. R. Maj, P. Bykowski, D. Dutkiewicz 


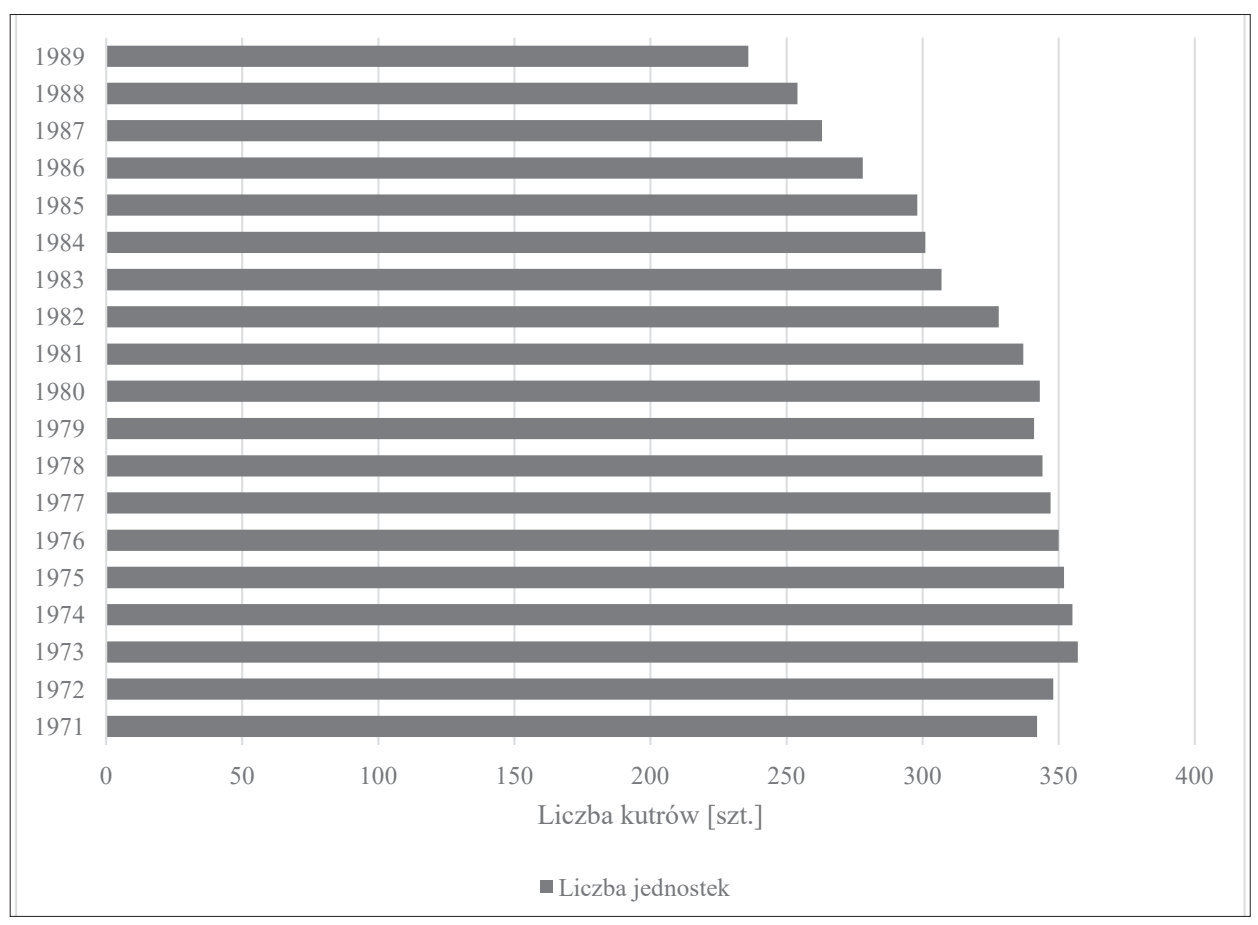

Rys. 1. Państwowa flota kutrowa eksploatowana przez PPiUR oraz SPRM na Morzu Bałtyckim w latach 1971-1989 [szt.]

Ź r ó d ł o: opracowanie własne na podstawie: Gospodarka rybna w latach 1971-1989. Materiały do badań, „Studia i Materiały MIR”, Seria E, nr 38, 40, 43, 44, 45, 47, 48, 49, Gdynia 1978-1991.

Początek lat dziewięćdziesiątych XX w. cechował się zmianami w strukturze własności i funkcjonowania przedsiębiorstw państwowych. Nie ominęły one jednostek gospodarki uspołecznionej tworzących branżę rybną. W ramach przyjętej 13 lipca 1990 r. Ustawy o prywatyzacji przedsiębiorstw państwowych zdecydowano o docelowej likwidacji kombinatów i spółdzielni,

i inni, Gdynia 1979, s. 117; Gospodarka rybna w latach 1975-1977. Materiały do badań, „Studia i Materiały MIR", Seria E, nr 43, red. B. Draganik, P. Bykowski, D. Dutkiewicz i inni, Gdynia 1979, s. 105; Gospodarka rybna w latach 1976-1978. Materiały do badań, „Studia i Materiały MIR”, Seria E, nr 44, red. B. Draganik, P. Bykowski, D. Dutkiewicz i inni, Gdynia 1982, s. 111; Gospodarka rybna w latach 1977-1979. Materiały do badań, „Studia i Materiały MIR”, Seria E, nr 45, brak redakcji, Gdynia 1984, s. 87; Gospodarka rybna w latach 1979-1981. Materiały do badań, „Studia i Materiały MIR”, Seria E, nr 47, red. P. Bykowski, H. Ganowiak, J. Krępa i inni, Gdynia 1986, s. 121; Gospodarka rybna w latach 1981-1983. Materiały do badań, „Studia i Materiały MIR", Seria E, nr 48, red. P. Bykowski, H. Ganowiak, J. Krępa i inni, Gdynia 1986, s. 105-106; Gospodarka rybna w latach 1983-1985. Materiały do badań, „Studia i Materiały MIR”, Seria E, nr 49, red. W. Borowski, P. Bykowski, H. Ganowiak i inni, Gdynia 1990, s. 102; Gospodarka rybna w latach 1986-1989..., tab. 5, tab. 6). 
gdzie w obu przypadkach ich miejsce miała zająć własność prywatna9. Odgórne decyzje dotyczyły także rozbudowanej floty kutrowej, która przez cały 1990 r. nie zmieniła swojej struktury, aczkolwiek zmniejszyła się liczba jednostek pozostających w eksploatacji wynosząca na koniec 1990 r. 210 sztuk $^{10}$.

Postępujący proces zmiany struktury własności we flocie na Morzu Bałtyckim wiązał się z wnoszeniem państwowych jednostek, początkowo na zasadzie leasingu, później zaś ajencji, dzierżawy, a ostatecznie zbycia rybakom indywidualnym ${ }^{11}$. Do jego realizacji zobligowano władze przedsiębiorstw lub spółdzielni, których zadaniem było rozdzielenie floty głównie między dawnych pracowników ${ }^{12}$. Od tej reguły odstępowano, czego potwierdzeniem było przekazywanie kutrów osobom wywodzącym się spośród przedsiębiorców prywatnych lub sprzedaż jednostek za granicę głównie do krajów afrykańskich ${ }^{13}$. W ten sposób w niespełna trzy lata państwowe pod-

9 Vide: Ustawa z dnia 13 lipca 1990 r. o prywatyzacji przedsiębiorstw państwowych (Dz.U. Nr 51, poz. 298, s. 695-700).

${ }_{10}$ Gospodarka rybna w latach 1990-1992, „Studia i Materiały MIR”, Seria E, red. J. Grzenia, M. Gustowska, E. Makowiecka i inni, Gdynia 1994, s. 27.

${ }^{11} \mathrm{~W}$ przypadku państwowych podmiotów tworzących rybołówstwo, w ramach gospodarki centralnie planowanej, podjęto się próby wyboru racjonalnej drogi prywatyzacji poszczególnych podmiotów. W początkowej fazie planowano tylko wyzbycie się floty kutrowej, którą uznano za najbardziej kosztochłonny element majątku. W późniejszym okresie próbowano sprzedawać przedsiębiorstwa w całości lub ich wydzielone fragmenty. Miało to pomóc w utrzymaniu stanu zbliżonego do ówczesnej rzeczywistości, gdzie jako priorytet uznano przetrwanie na rynku poszczególnych podmiotów. Ostatecznie w przypadku przedsiębiorstw państwowych, wyłączając „Szkuner”, prywatyzacja zakończyła się ich upadkiem. Spółdzielnie po rezygnacji z eksploatacji floty przeniosły swoją działalność do sektora produkcyjnego („,Łosoś”) lub usługowego („Gryf”) (AEK MIR, Z. Polański, Z. Russek, Propozycje i warunki przekształceń własnościowych $w$ polskiej gospodarce rybnej /projekt wstępny/, Gdynia 1990, [maszynopis niepublikowany], s. 21-30; AEK MIR, E. Kuzebski, Analiza przeksztatceń własnościowych i strukturalnych w państwowych przedsiębiorstwach połowowych, Gdynia 1995, [maszynopis niepublikowany], s. 5-6).

12 Wyzbycie się floty pozwoliło na spłacenie bieżących zobowiązań poszczególnych podmiotów. Ostatecznie część najnowocześniejszych (B-410, B-403, B-280, TMC-001) jednostek trafiła w ręce bardzo wąskiej grupy osób (AEK MIR, E. Kuzebski, Ocena efektów ekonomicznych zmian strukturalnych i własnościowych w państwowych przedsiębiorstwach połowowych, Gdynia 1996, [maszynopis niepublikowany], s. 8; AEK MIR, Z. Polański, Z. Russek, Propozycje i warunki przekształceń własnościowych w polskiej gospodarce rybnej /projekt wstępny/, Gdynia 1990, [maszynopis niepublikowany], s. 28).

${ }^{13}$ Wyzbywanie się jednostek za granicę rozpoczęto na przełomie 1992 i 1993 r. Kutry przekazywano armatorom zagranicznym w Afryce głównie za pośrednictwem BHZ „Rybex" lub banków, które udzielały przedsiębiorstwom kredytów. Łączna liczba sprzedanych statków nie jest znana do dziś, aczkolwiek zachowała się część danych dotyczących tego zagadnienia. PPiUR „Koga” w 1993 i 1995 r. sprzedało do Namibii i RPA: Hel-151, Hel-153, Hel-154. PPiUR „Szkuner” po 1993 r. sprzedało do Namibii: Wła-290 oraz Wła-308, PPiUR „Korab” w Ustce 
mioty wyzbyły się jednego z najważniejszych elementów majątku trwałego, co przyczyniło się do odcięcia od surowca niezbędnego do produkcji i ich późniejszego regresu. Proceder ten postulowany przez kręgi naukowe miał działać zupełnie inaczej, opierając się na teoretycznym mechanizmie samoregulacji rynku, który w praktyce nie zadziałał ${ }^{14}$.

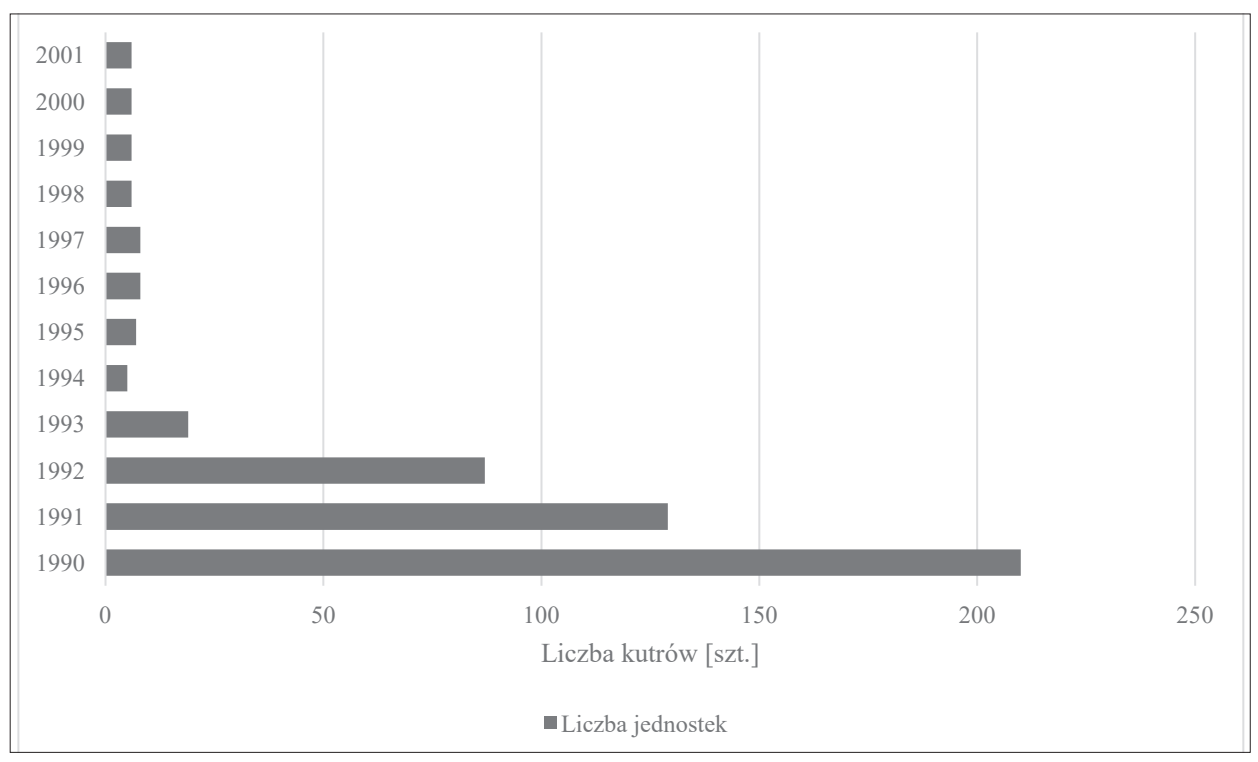

Rys. 2. Państwowa flota kutrowa eksploatowana przez PPiUR oraz SPRM na Morzu Bałtyckim w latach 1990-2001 [szt.]

Źródło: Opracowanie własne na podstawie: Gospodarka rybna w latach 1990-1996, „Studia i Materiały MIR", Seria E, nr 50, 52, 53, 56, 57, Gdynia 1994-1998; Rybołówstwo polskie 1996-2002, „Studia i Materiały MIR”, Seria E, nr 55, 58, 59, 61, 63, 64, 66, Gdynia 1998-2004.

sprzedało do Namibii: Ust-78, Ust-80, Ust-81, Ust-82, Ust-200, Ust-201, PPiUR „Kuter” w Darłowie sprzedało: Dar-312, Dar-314, Dar-315, PPiUR „Barka” w Kołobrzegu sprzedało: Koł-176, Koł-184 (AF PPiUR „Koga”, brak sygnatury, Sprzedaż Hel 153 Hel 154, Agreement between Cadilu Fishing PTY Ltd. and crew of the Hel 154, b.p.; AF PPiUR „Koga”, brak sygnatury, Sprzedaż Hel 153 Hel 154, Fax z 13.03.1993 r., b.p.; AF PPiUR „Koga”, brak sygnatury, Sprzedaż Hel 153 Hel 154, Memorandum of agreement, k. 1; Rozmowa z armatorem kutra Hel-152 Edwardem Koreńczukiem, [w kolekcji autora]).

${ }^{14}$ Teoretyczne założenia procesu prywatyzacji zakładały stopniowe przejście od własności państwowej do prywatnej. Podstawą miały być zasady wolnej konkurencji oraz samoregulacji rynku. Przedsiębiorstwa powinny w początkowej fazie ograniczyć koszty, a następnie podzielić majątek i sprzedać go tworząc system kooperujących ze sobą firm w ramach otoczenia podmiotu. Podjęto próby sprzedaży majątków jako całości, ale w żadnym z przypadków transakcji nie sfinalizowano (AEK MIR, E. Kuzebski, Analiza przekształceń własnościowych i strukturalnych w państwowych przedsiębiorstwach połowowych, Gdynia 1995, [maszynopis niepublikowany], s. 48-57). 
Zaprezentowane na rys. 2. dane odnoszą się do okresu transformacji polskiego rybołówstwa na Morzu Bałtyckim. Uwidoczniła się tam silna tendencja do obniżenia posiadanego potencjału połowowego i ostatecznego zbycia na rzecz rybaków indywidualnych. Analizując ubytek badanej zmiennej, w początkowym okresie flota znajdująca się w eksploatacji przedsiębiorstw państwowych zmniejszyła się o niemal 40 procent, a spółdzielcza o ponad 30 procent. Był to spadek znaczny, aczkolwiek w pierwszej fazie przekształceń własnościowych wycofywano ze służby głównie jednostki cechujące się starszym wiekiem ${ }^{15}$. Od 1992/1993 r. rozpoczęto proces oddawania w leasing kutrów rufowych, ważnych z punktu widzenia funkcjonowania całej branży ${ }^{16}$. Proces ten był powszechny i finalnie spowodował trudności w zaopatrywaniu przedsiębiorstw w surowiec niezbędny do produkcji ${ }^{17}$. Redukcja przeprowadzona na przestrzeni lat 1990-1993 była wstępnym etapem, w większości nieudanego procesu prywatyzacyjnego państwowego majątku, gdzie finalnie przetrwało niewiele podmiotów, przy tym działalność połowową prowadzi tylko „Szkuner” we Władysławowie ${ }^{18}$.

Ważnym zagadnieniem jest struktura floty znajdującej się w eksploatacji państwowych przedsiębiorstw. Została ona zaprezentowana w tabeli 1. W badanym okresie przypadającym na lata 1971-2001 miały miejsce znaczne przekształcenia państwowej floty kutrowej. W pierwszych pięciu latach analizy składała się ona niemal wyłącznie z burtowców, gdzie wyjątek stanowił jeden kuter rufowy typu TR-27 (wprowadzony do służby w 1967 r.), a później trawler typu B-410 wprowadzony w $1974 \mathrm{r}^{19}$. Pierwsze widoczne zmiany struktury jednostek należących do kombinatów są ściśle związane z trzecią modernizacją floty, której efektem było masowe wprowadzanie do linii kutrów rufowych najpierw, przeznaczonych na rynek

15 Przykładem takiej działalności była rezygnacja z eksploatacji jednostek typu B-25s (AEK MIR, Z. Polański, S. Szostak, Analiza ekonomiczna rybołówstwa morskiego za 1990 rok, Gdynia 1991, s. 29).

${ }^{16}$ W 1990 r. PPiUR eksploatowały łącznie 151 kutrów, 1991 r. - 91 kutrów, w 1992 r. - 63 kutry, w 1993 r. - 18 kutrów, w 1994 - 4 kutry, w 1995 r. - 4 kutry, w 1995 r. - 6 kutrów, w 1996 r. - 8 kutrów, w 1997 r. - 8 kutrów, w 1998 r. - 6 kutrów i liczba ta pozostała niezmieniona do końca badanego okresu. W 1990 r. SPRM eksploatowały łącznie 59 kutrów, w 1991 r. - 38 kutrów, w 1992 r. - 24 kutry, w 1993 r. - 1 kuter, w 1994 r. - 1 kuter. Od 1995 r. SPRM nie prowadziło żadnych operacji połowowych na Morzu Bałtyckim (Gospodarka rybna w latach 1990-1992..., s. 26-28; Gospodarka rybna w latach 1992-1994, „Studia i Materiały MIR”, Seria E, nr 53, red. J. Grzenia, M. Gustowska, E. Kuzebski, Gdynia 1996, s. 31-32).

17 S. Szostak, Polskie rybołówstwo w latach 1990-1995, „Studia i Materiały Morskiego Instytutu Rybackiego", Seria E, nr 54, Gdynia 1996, s. 7-9.

${ }^{18}$ R. Białkowski, H. Gawlas, H. Spigarski, „Szkuner” Port-Szkuner - Miasto, Gdańsk 2005, s. 79.

${ }^{19}$ H. Spigarski, Stocznia remontowa Nauta S.A. Dla marzeń i wyzwań, Gdańsk 2006, s. 37. 
krajowy typu B-410 (65 sztuk) ${ }^{20}$, a później ich wersji eksportowej wstępnie przeznaczonej dla państwowych kombinatów połowowych w NRD, oznaczonych B-403 (14 sztuk), finalnie z nielicznymi wyjątkami przekazanych przedsiębiorstwom $w$ kraju $^{21}$. Rozpoczęto proces wyłączenia $\mathrm{z}$ flot znajdujących się w eksploatacji pięciu PPiUR, jednostek wysłużonych, posiadających kadłuby stalowo-drewniane (kompozytowe) reprezentujących typy B-12 oraz B-25. Z punktu widzenia ekonomiki było to posunięcie dobre, ponieważ obok rzeczywistego unowocześnienia i automatyzacji procesów połowowych podjęto próbę utrzymania wydajności połowowej. Za punkt szczytowy należało uznać rok 1991, kiedy kończono wprowadzanie do służby najnowszych trawlerów typu B-280 (18 szt.) oraz TMC-001 (2 szt.), które były efektem piątej i zarazem ostatniej fali modernizacyjnej państwowej floty kutrowej ${ }^{22}$.

${ }^{20} \mathrm{~W}$ ramach trzeciej fazy modernizacji wprowadzono do służby następujące jednostki typu B-410: Hel-100, Hel-101 (1976 r.), Hel-102, Hel-130 (1977 r.), Hel-128, Hel-131 (1978 r.) dla PPiUR „Koga” w Helu; Wła-300 (1974 r.), Wła-301 (1975 r.), Wła-302, Wła303 (1976 r.), Wła-298, Wła-299, Wła-304 (1977 r.), Wła-307 (1979 r.), Wła-305, Wła-306 (1980 r.), Wła-308 (1982 r.) dla PPiUR „Szkuner” we Władysławowie; Ust-84, Ust-85, Ust-86, Ust-87 (1976 r.), Ust-79, Ust-80, Ust-81 (1978 r.), Ust-78, Ust-82, Ust-83 (1979 r.), Ust-200, Ust-201 (1980 r.), Ust-202, Ust-203 (1981 r.) dla PPiUR „Korab” w Ustce, Dar-300, Dar-301, Dar-302 (1976 r.), Dar-303 (1977 r.), Dar-304 (1978 r.), Dar-305, Dar-306 (1979 r.), Dar306, Dar-307, Dar-309, Dar-310, Dar-311 (1980 r.), Dar-312 (1982 r.), Dar-313 (1983 r.) dla PPiUR „Kuter” w Darłowie; Koł-173, Koł-174 (1976 r.), Koł-176, Koł-177, Koł-178, Koł-179, Koł-180, Koł-181 (1980 r.), Koł-186 (1979 r.), Koł-187, Koł-188, Koł-189, Koł-190 (1980 r.), Koł-191, Koł-192 (1981 r.), Koł-193 (1982 r.), dla PPiUR „Barka” w Kołobrzegu; Koł-9, Koł-10 (1981 r.), Koł-8, Koł-11 (1983 r.) dla SPRM „Bałtyk” w Kołobrzegu (Gospodarka rybna w latach 1986-1989..., tab. 98; W. Blady, Polska flota rybacka w latach 1921-2001. Kalendarium tragicznych zdarzeń na statkach rybackich w latach 1945-2001, Gdynia 2002, s. 80; M. Kubicki, Modernizacja floty PPiUR „Koga” w Helu. Wprowadzenie do służby trawlerów rufowych typu B-410 w latach 1974-1980, „Zapiski Puckie”, 2016, r 15, s. 137-138).

${ }^{21} \mathrm{~W}$ ramach czwartej fazy modernizacji państwowej floty wprowadzono do służby następujące jednostki typu B-403: Wła-290, Wła-291, Wła-292 (1978 r.), Wła-288, Wła-289, Wła-293, Wła-294, Wła-295, Wła-296, Wła-297 (1978 r.) dla PPiUR „Szkuner” we Władysławowie; Koł-182, Koł-183, Koł-184, Koł-185 (1979 r.) dla PPiUR „Barka” w Kołobrzegu (Gospodarka rybna w latach 1986-1989..., tab. 98; W. Blady, Polska flota rybacka..., s. 81; R. Leszczyński, Tragedie rybackiego..., t. 1, 29-30).

${ }^{22} \mathrm{~W}$ ramach ostatniej fazy modernizacji państwowej floty kutrowej przypadającej na lata 1988-1992 wprowadzono następujące jednostki TMC-001: Koł-194 (1991 r.), Koł-195 (1992 r.) obie dla PPiUR „Barka” w Kołobrzegu. Jednostki typu B-280: Hel-150, Hel-151 (1988 r.), Hel 152 (1989 r.), Hel-153 (1990 r.), Hel-154 (1991 r.) dla PPiUR „Koga” w Helu; Wła-310 (1989 r.), Wła-311, Wła-312 (1990 r.) dla PPiUR „Szkuner” we Władysławowie; Ust-204 (1989 r.), Ust-205, Ust-206 (1990 r.) dla PPiUR „Korab” w Ustce; Dar-314, Dar315 (1989 r.), Dar-316 (1990 r.) dla PPiUR „Kuter” w Darłowie; Koł-6, Koł-7 (1991 r.) dla PPiUR „Barka” w Kołobrzegu. Dodatkowo dwie z budowanej serii jednostek przekazano armatorom indywidualnym Koł-120 (wcześniejszy Hel-155) oraz Koł-121 (W. Blady, Polska 
Tabela 1

Skład ilościowy floty kutrowej eksploatowanej przez PPiUR na Morzu Bałtyckim w latach 1971-2001

\begin{tabular}{|c|c|c|c|c|}
\hline \multirow[b]{2}{*}{ Rok } & \multicolumn{2}{|c|}{ Liczba jednostek [szt.] } & \multicolumn{2}{|c|}{ Skład ilościowy [\%] } \\
\hline & $\begin{array}{c}\text { Kutry } \\
\text { burtowe }\end{array}$ & $\begin{array}{c}\text { Trawlery } \\
\text { rufowe }\end{array}$ & $\begin{array}{c}\text { Kutry } \\
\text { burtowe }\end{array}$ & $\begin{array}{c}\text { Trawlery } \\
\text { rufowe }\end{array}$ \\
\hline 1971 & 225 & 1 & 99,56 & 0,44 \\
\hline 1972 & 231 & 1 & 99,57 & 0,43 \\
\hline 1973 & 241 & 1 & 99,59 & 0,41 \\
\hline 1974 & 239 & 1 & 99,58 & 0,42 \\
\hline 1975 & 236 & 2 & 99,16 & 0,84 \\
\hline 1976 & 225 & 10 & 95,74 & 4,26 \\
\hline 1977 & 219 & 19 & 92,02 & 7,98 \\
\hline 1978 & 194 & 33 & 85,46 & 14,54 \\
\hline 1979 & 174 & 52 & 76,99 & 23,01 \\
\hline 1980 & 160 & 68 & 70,18 & 29,82 \\
\hline 1981 & 149 & 72 & 67,42 & 32,58 \\
\hline 1982 & 136 & 74 & 64,76 & 35,24 \\
\hline 1983 & 120 & 75 & 61,54 & 38,46 \\
\hline 1984 & 116 & 75 & 60,73 & 39,27 \\
\hline 1985 & 115 & 74 & 60,85 & 39,15 \\
\hline 1986 & 103 & 74 & 58,19 & 41,81 \\
\hline 1987 & 97 & 74 & 56,73 & 43,27 \\
\hline 1988 & 87 & 76 & 53,37 & 46,63 \\
\hline 1989 & 71 & 80 & 47,02 & 52,98 \\
\hline 1990 & 62 & 87 & 41,61 & 58,39 \\
\hline 1991 & 15 & 76 & 16,48 & 83,52 \\
\hline
\end{tabular}

flota rybacka..., s. 83; M. Kubicki, Modernizacja floty rybackiej Przedsiębiorstwa Połowów i Usług Rybackich „Koga” w Helu - budowa i wprowadzenie do służby kutrów rybackich typu B-280 w latach 1986-1991, [w:] Additamenta Historica. Studia z dziejów dalekich i bliskich, red. B. Klassa, Gdańsk 2016, s. 199-210; D. Duda, B. Wandtke, Port Hel. Przyczynek do 100-letniej historii, Gdynia 1993, s. 38). 


\begin{tabular}{|c|c|c|c|c|}
\hline \multirow{2}{*}{ Rok } & \multicolumn{2}{|c|}{ Liczba jednostek [szt.] } & \multicolumn{2}{c|}{ Skład ilościowy [\%] } \\
\cline { 2 - 5 } & $\begin{array}{c}\text { Kutry } \\
\text { burtowe }\end{array}$ & $\begin{array}{c}\text { Trawlery } \\
\text { rufowe }\end{array}$ & $\begin{array}{c}\text { Kutry } \\
\text { burtowe }\end{array}$ & $\begin{array}{c}\text { Trawlery } \\
\text { rufowe }\end{array}$ \\
\hline 1992 & 10 & 53 & 15,87 & 84,13 \\
\hline 1993 & 4 & 14 & 22,22 & 77,78 \\
\hline 1994 & 0 & 4 & 0,00 & 100,00 \\
\hline 1995 & 0 & 4 & 0,00 & 100,00 \\
\hline 1996 & 0 & 6 & 0,00 & 100,00 \\
\hline 1997 & 0 & 6 & 0,00 & 100,00 \\
\hline 1998 & 0 & 6 & 0,00 & 100,00 \\
\hline 1999 & 0 & 6 & 0,00 & 100,00 \\
\hline 2000 & 0 & 6 & 0,00 & 100,00 \\
\hline 2001 & 0 & 6 & 0,00 & 100,00 \\
\hline
\end{tabular}

Źródło: opracowanie własne na podstawie: Gospodarka rybna w latach 1971-1996. Materiały do badań, „Studia i Materiały MIR”, Seria E, nr 38, 40, 43, 44, 45, 47, 48, 49, 50, 52, 53, 56, 57, Gdynia 1978-1998; Rybołówstwo polskie 1996-2002, „Studia i Materiały MIR”, Seria E, nr 55, 58, 59, 61, 63, 64, 66, Gdynia 1998-2004.

Rozpoczęta w 1990 r. procedura prywatyzacji przedsiębiorstw państwowych obok wyzbycia się majątku nieprodukcyjnego dotyczyła także floty kutrowej. Zgodnie z przyjętymi wytycznymi na początku wyzbywano się głównie jednostek burtowych, które cechowały się starszym wiekiem² ${ }^{23}$. Należy wskazać, że podstawową metodą redukcji kosztów związanych $\mathrm{z}$ utrzymaniem jednostek było ich oddawanie w leasing byłym pracownikom przedsiębiorstw państwowych oraz innym podmiotom ${ }^{24}$. Stopniowo redukowano flotę rufowców, jednakże jak wynika z danych zamieszczonych w tabeli 1, proces ten przez pierwsze dwa lata nie cechował się dużą dynamiką, co mogło wskazywać, jakoby dyrekcje przedsiębiorstw planowały zachować część jednostek w eksploatacji ${ }^{25}$. Finalnie tak się nie stało, co

${ }^{23}$ Przykładem takiej działalności było oddawanie jednostek w leasing rybakom indywidualnym. Na przykład w marcu 1991 r. w PPiUR „Koga” w Helu oddano wszystkie 9 jednostek typu B-25s/A (AEK MIR, S. Szostak, Z. Russek, Analiza ekonomiczno-finansowa Przedsiębiorstwa Połowów i Usług Rybackich „Koga” w Helu za lata 1988-1990 i pierwsze półrocze 1991 r., [brak daty i miejsca wydania, maszynopis niepublikowany], s. 7).

${ }^{24}$ AF PPiUR „Koga”, Zespół dokumenty sprzedaży kutrów, brak sygn., Hel 108, Hel 109, Hel 110, Hel 111, Hel 136, Hel 137, Hel 138, Hel 139, Hel 140, Hel 141, Hel 142, Hel 143, Hel 144, Hel 145.

${ }^{25}$ Przykładem ograniczenia składu flot jest ich stan w 1992 r. Przedsiębiorstwa państwowe planowały zachować następującą liczbę jednostek: PPiUR „Koga” w Helu - 12 szt. 
spowodowało odcięcie kombinatów od dostaw surowca ${ }^{26}$. Ostatecznie spośród pięciu państwowych przedsiębiorstw połowowych od 1994 r. flotę eksploatował tylko PPiUR "Szkuner” we Władysławowie oraz przejściowo w latach 1995-1997 nowopowstałe przedsiębiorstwo „Dalmor-Bałtyk” Sp. z o.o.

\section{Tabela 2}

Skład ilościowy floty kutrowej eksploatowanej przez SPRM na Morzu Bałtyckim w latach 1971-1995

\begin{tabular}{|c|c|c|c|c|}
\hline \multirow{2}{*}{ Rok } & \multicolumn{2}{|c|}{ Liczba jednostek [szt.] } & \multicolumn{2}{c|}{ Skład ilościowy [\%] } \\
\cline { 2 - 5 } & $\begin{array}{c}\text { Kutry } \\
\text { burtowe }\end{array}$ & $\begin{array}{c}\text { Trawlery } \\
\text { rufowe }\end{array}$ & $\begin{array}{c}\text { Kutry } \\
\text { burtowe }\end{array}$ & $\begin{array}{c}\text { Trawlery } \\
\text { rufowe }\end{array}$ \\
\hline 1971 & 116 & 0 & 100,00 & 0,00 \\
\hline 1972 & 116 & 0 & 100,00 & 0,00 \\
\hline
\end{tabular}

(6 B-410, 1 TR-27, 5 B-280), PPiUR „Szkuner” we Władysławowie - 3 szt. (3 B-280), PPiUR „Korab” w Ustce - 12 szt. (9 B-410, 3 B-280), PPiUR „Kuter” w Darłowie - 16 szt. (13 B-410, 3 B-280), PPiUR „Barka” w Kołobrzegu - 22 szt. (2 TMC-001, 16 B-410, 4 B-403). Należy więc uznać, że wstępnie planowano zachować w służbie najbardziej wydajne i najnowocześniejsze kutry. Wraz z postępującym procesem prywatyzacji, wyłączając PPiUR „Szkuner”, pozostałe podmioty wyzbyły się reszty jednostek (Gospodarka rybna w latach 1991-1993, „Studia i Materiały MIR", Seria E, nr 52, red. J. Grzenia, M. Gustowska, E. Makowiecka i inni, Gdynia 1995, s. 98).

${ }^{26}$ Upadłość poszczególnych PPiUR przebiegała stopniowo. PPiUR „Koga” w Helu ogłosiło upadłość w 2001 r. Przedsiębiorstw zostało rozdzielone na szereg spółek, a ostatnie części majątku zostały wykupione przez Gdańską Korporację Handlową w 1998 r. PPiUR „Szkuner” poddano tylko zabiegom ograniczającym koszty generowane przez majątek nieprodukcyjny. W 1990 r. powołano także giełdę zajmującą się skupem ryby od rybaków indywidualnych. Majątek produkcyjny nie został rozdzielony. PPiUR „Korab” w Ustce podjął się działań naprawczych, ale do $1996 \mathrm{r}$. nie przynosiły one spodziewanych rezultatów. Ostatecznie przedsiębiorstwo ogłosiło upadłość pod koniec lat dziewięćdziesiątych XX w. PPiUR „Kuter” w Darłowie podjął próbę przeprowadzenia przekształceń, ale do $1998 \mathrm{r}$. nie przynosiły one rezultatów. Nie udało się pozyskać strategicznego inwestora. Ostatecznie „Kuter” po objęciu zarządem komisarycznym ogłosił upadłość w 2001 r. W PPiUR „Barka” próby restrukturyzacji zakończyły się fiaskiem. Wyzbyto się majątku nieprodukcyjnego oraz zlikwidowano fabrykę mączki rybnej. Przedsiębiorstwo upadło w 1996 r. (AEK MIR, E. Kuzebski, Analiza przekształceń własnościowych i strukturalnych w państwowych przedsiębiorstwach połowowych, Gdynia 1995, [maszynopis niepublikowany], s. 48; K. Kołodziej, Przedsiębiorstwa przetwórstwa rybnego w Polsce, „Wiadomości Rybackie”, 1994, nr 5, s. 3; Rybołówstwo polskie 1998, „Studia i Materiały MIR”, Seria E, nr 59, red. S. Szostak, E. Kuzebski, B. Pieńkowska i inni, Gdynia 2000, s. 5; P. Kuciewicz, O śledziu i prywatyzacji, „Wiadomości Rybackie”, 1993, nr 2, s. 7; P. Kuciewicz, Przełomowy rok „Korabia”, „Wiadomości Rybackie”, 1996, nr 7, s. 5-6; M. Loos, Prywatyzacja darłowskiego „Kutra”, „Wiadomości Rybackie”, 1995, nr 6, s. 6; P. Kuciewicz, Tonąca „Barka”, „Wiadomości Rybackie", 1996, nr 6, s. 15; S. Szostak, Polskie rybołówstwo w latach 1990-1995..., s. 8). 


\begin{tabular}{|c|c|c|c|c|}
\hline \multirow{2}{*}{ Rok } & \multicolumn{2}{|c|}{ Liczba jednostek [szt.] } & \multicolumn{2}{|c|}{ Skład ilościowy [\%] } \\
\hline & $\begin{array}{c}\text { Kutry } \\
\text { burtowe }\end{array}$ & $\begin{array}{c}\text { Trawlery } \\
\text { rufowe }\end{array}$ & $\begin{array}{c}\text { Kutry } \\
\text { burtowe }\end{array}$ & $\begin{array}{c}\text { Trawlery } \\
\text { rufowe }\end{array}$ \\
\hline 1973 & 115 & 0 & 100,00 & 0,00 \\
\hline 1974 & 115 & 0 & 100,00 & 0,00 \\
\hline 1975 & 114 & 0 & 100,00 & 0,00 \\
\hline 1976 & 115 & 0 & 100,00 & 0,00 \\
\hline 1977 & 115 & 0 & 100,00 & 0,00 \\
\hline 1978 & 117 & 0 & 100,00 & 0,00 \\
\hline 1979 & 117 & 0 & 100,00 & 0,00 \\
\hline 1980 & 117 & 0 & 100,00 & 0,00 \\
\hline 1981 & 113 & 2 & 98,26 & 1,74 \\
\hline 1982 & 114 & 2 & 98,28 & 1,72 \\
\hline 1983 & 108 & 4 & 96,43 & 3,57 \\
\hline 1984 & 106 & 4 & 96,36 & 3,64 \\
\hline 1985 & 103 & 4 & 96,26 & 3,74 \\
\hline 1986 & 97 & 4 & 97,98 & 4,04 \\
\hline 1987 & 88 & 4 & 95,65 & 4,35 \\
\hline 1988 & 87 & 4 & 95,60 & 4,40 \\
\hline 1989 & 81 & 4 & 95,29 & 4,71 \\
\hline 1990 & 55 & 4 & 93,22 & 6,78 \\
\hline 1991 & 33 & 5 & 86,84 & 13,16 \\
\hline 1992 & 23 & 1 & 95,83 & 4,17 \\
\hline 1993 & 0 & 1 & 0,00 & 100,00 \\
\hline 1994 & 0 & 1 & 0,00 & 100,00 \\
\hline 1995 & 0 & 1 & 0,00 & 100,00 \\
\hline
\end{tabular}

Źródło: opracowanie własne na podstawie: Gospodarka rybna w latach 1971-1996. Materiały do badań, „Studia i Materiały MIR”, Seria E, Nr 38, 40, 43-45, 47-50, 52, 53, 56, 57, Gdynia 1978-1998; Rybołówstwo polskie 1996-2002, „Studia i Materiały MIR”, Seria E, Nr 55, 58, 59, 61, 63, 64, 66, Gdynia 1998-2004. 
Podobną zależność względem przedsiębiorstw państwowych wykazywała flota kutrowa znajdująca się w eksploatacji spółdzielni. Przez pierwsze 10 lat badanego okresu składała się wyłącznie z jednostek burtowych, jednakże były to kutry mniejsze, określone przez twórców statystyk jako „kutry 17 metrowe"27. Wraz z postępującymi fazami modernizacji państwowej floty kutrowej dokonywano przeobrażeń floty spółdzielczej. Wyrazem tego było oddanie do eksploatacji SPRM „Jedność Rybacka” w Gdańsku najpierw ośmiu kutrów typu B-25s ${ }^{28}$, dwóch B-25s/ $\mathrm{B}^{29}$, a następnie czterech kutrów burtowych typu B-25s/A $\mathrm{A}^{30}$ oraz realizowany od $1978 \mathrm{r}$. proces wprowadzania do służby kutrów typu KB-21 i KŁ-2131. Jednakże pierwsza zmiana struktury floty miała miejsce dopiero w 1981 r., kiedy zdecydowano, że SPRM „Bałtyk” w Kołobrzegu otrzymała dwie jednostki typu B-410 (Koł-8, Koł-9).

Wraz z postępującym procesem modernizacyjnym rozpoczęto stopniowe wycofywanie ze służby najstarszych jednostek. Kasacje dotyczyły głównie burtowych kutrów 17 metrowych, które w prezentowanym okresie stanowiły główny filar spółdzielczego rybołówstwa na Morzu Bałtyckim. Dzięki wyposażeniu poszczególnych podmiotów w jednostki o mniejszych możliwościach połowowych flota eksploatowana przez spółdzielnie zawsze łowiła mniej ryby niż państwowe kombinaty. Największe zmiany w strukturze flot eksploatowanych przez SPRM wypadały na 1991 r., kiedy kutry rufowe stanowiły ponad $13 \%$ całości, ale było to związane z postępującym procesem restrukturyzacji ${ }^{32}$.

${ }^{27} \mathrm{~W}$ celu unowocześnienia i wzmocnienia flot eksploatowanych przez SPRM zasilono je liczną grupą jednostek określonych jako „kuter 17 m”. W skład tej kategorii wchodziły głównie jednostki burtowe typów Storem 4B oraz Storem 4C.

${ }^{28}$ Były to: Gda-8, Gda-9, Gda-10, Gda-11, Gda-12, Gda-13, Gda-14, Gda-15.

${ }^{29}$ Były to: Gda-18 i Gda-19.

30 Były to: Gda-16, Gda-17, Gda-20, Gda-21 (Gospodarka rybna w latach 1986-1989..., tab. 98).

${ }^{31}$ Jednostki burtowe typów KB-21 (kuter burtowy 21 metrowy) oraz KŁ-21 (kuter łososiowy 21 metrowy) były ważnym wzmocnieniem flot znajdujących się w eksploatacji SPRM. Łącznie oddano do służby 21 jednostek typu KB-21 oraz 6 typu KŁ-21. Kutry wchodziły do służby w następującej kolejności: 1978 r. - Wła-250 (KŁ-21, SPRM „Gryf”), Ust-6, Ust 7 (SPRM „Łosoś”) Dzi-16 (SPRM „Belona”), 1979 r. - Wła-251, Wła-252 (KŁ-21, SPRM „Gryf”), Dzi-17, Dzi-29 (SPRM „Belona”), 1980 r. - Wła-253, Wła-254 (KŁ-21, SPRM „Gryf”), Dzi-31 (SPRM „Belona”), 1981 r. - Ust-8, Ust-9 (SPRM „Łosoś”), 1982 r. - Ust-10 (KŁ-21, SPRM „Łosoś”), Dzi-41 (SPRM „Belona”), Ust-73 (SPRM „Łosoś), 1983 r. - Ust-75 (SPRM „Łosoś”), 1984 r. - Łeb-1 (SPRM „Rybmor”), 1985 r. - Łeb-5 (SPRM „Rybmor”), 1986 r. - Łeb-9, Łeb-10 (SPRM „Rybmor”), 1987 r. - Łeb-12 (SPRM „Rybmor”), 1988 r. - Łeb-20 (SPRM „Rybmor”), Ust-1 (SPRM „Łosoś"), 1989 r. - Ust-2 (SPRM „Łosoś”), Wła-160, Wła-161 (SPRM „Gryf”) (ibidem, tab. 98).

32 Było to związane ze zmniejszaniem się udziału burtowców w całości floty. Jednostki te wycofywano, ponieważ uznawano je za wyeksploatowane. Po wprowadzeniu do służby wskazanych wcześniej czterech trawlerów rufowych typu B-410 flota znajdująca się w eks- 
Analogicznie jak w przypadku przedsiębiorstw państwowych rozpoczęta w 1990 r. prywatyzacja majątków spółdzielni wymusiła na poszczególnych zarządach dokonanie stosownych redukcji flot ${ }^{33}$. W pierwszej kolejności oddano w leasing jednostki 17 metrowe, które w momencie przekazywania można było uznać za wyeksploatowane ${ }^{34}$. Dodatkowo SPRM „Jedność Rybacka" w Gdańsku w 1990 r. wyzbyła się czterech jednostek typu B-25s oraz B-25s/B, które również cechowały się starszym wiekiem ${ }^{35}$. Zgodnie z zachowanymi informacjami w eksploatacji planowano pozostawić tylko najnowsze burtowce typu KB-21 i KŁ-21, trawlery rufowe typu B-410 oraz wprowadzony do służby w 1991 r. pojedynczy kuter typu B-280. Rozpoczęto jednak wyzbywanie się poszczególnych jednostek, zakończając połowy w grudniu $1995 \mathrm{r}^{36}$ Proces przekształceń własnościowych spowodował redukcję liczby podmiotów wchodzących do kategorii SPRM, aczkolwiek część z nich przetrwała okres transformacji i kontynuowała działalność po $2001 \mathrm{r}^{37}$

Jedną z kwestii związanych z eksploatacją państwowej floty kutrowej na Morzu Bałtyckim były średnia wielkość jednostki oraz uśredniona moc siłowni głównej. Stosowne dane ilustrujące zmiany zaprezentowano na rysunku 3.

ploatacji SPRM wzbogaciła się o pojedynczy trawler typu B-280. Uwzględniając ogólny spadek ilościowy w kategorii burtowców, to właśnie ten czynnik miał największy wpływ na zmianę struktury floty.

${ }^{33}$ Jak wskazano wcześniej było to powiązane z ujemnym bilansem eksploatacji floty oraz zwiększaniem się kosztów połowów przy jednoczesnym spadku wydajności. Zygmunt Polański wskazywał, że sytuacja ta miała najbardziej negatywny wpływ na segment jednostek określanych jako „kutry 17 metrowe”, B-25s i B-25s/B (AEK MIR, Z. Polański, Sytuacja polskiego rybołówstwa. Nakład połowowy, połowy, efekty, limity, Gdynia 1991, [maszynopis niepublikowany], s. 5).

${ }^{34}$ Kończące serię kutry 17 metrowe zostały wprowadzone do służby w 1971 r, a więc w momencie przekazywania w leasing miały ponad 20 lat w czynnej służbie (Gospodarka rybna w latach 1986-1989..., tab. 98).

35 Znajdujące się w eksploatacji SPRM kutry typu B-25s wprowadzano do służby na przestrzeni lat 1959-1968, typu B-25s/B w 1971 r., a B-25s/A w 1975 r. Wyłączając ostatnią kategorię, pozostałe jednostki były w służbie przez ponad 20 lat (ibidem, tab. 98).

36 Ostatnią spółdzielnią posiadającą w eksploatacji pojedynczy trawler typu B-280 była SPRM „Bałtyk” w Kołobrzegu. W 1995 r. władze spółdzielni zrezygnowały z eksploatacji jednostki (S. Szostak, Polskie rybołówstwo w latach 1990-1995..., s. 8).

${ }^{37}$ Na podstawie wpisów do KRS udało się ustalić losy poszczególnych podmiotów. SPRM „Jedność Rybacka” w Gdańsku została wykreślona z rejestru przedsiębiorstw w 2008 r. SPRM „Gryf” we Władysławowie po dokonaniu przekształceń własnościowych aktualnie zajmuje się elementami wyposażenia kutrów rybackich. SPRM „Rybmor” w Łebie znajduje się w likwidacji od 2003 r. SPRM "Łosoś” w Ustce jest aktualnie jednym z wiodących producentów konserw rybnych. SPRM „Bałtyk” w Kołobrzegu znajduje się w likwidacji od $2003 \mathrm{r}$. SPRM „Belona” w Dziwnowie została zlikwidowana w połowie lat dziewięćdziesiątych XX w. SPRM „Ławica” w Darłowie została zlikwidowana w 2001 r. SPRM „Certa” w Szczecinie aktualnie znajduje się w likwidacji (ostatni wpis do rejestru w 2018 r.) (Dane na podstawie: http://www.krs-online.com.pl, dostęp: 27.08.2018). 
W przypadku pierwszej zmiennej była ona uzależniona od liczby jednostek znajdujących się w czynnej eksploatacji oraz wprowadzanych do służby większych kutrów, co dotyczyło typów B-410, B-403 oraz B-28038. Dodatkowo po 1990 r. uwidoczniły się tendencje do wyzbywania się ze składów flot państwowych kombinatów jednostek starszych posiadających mniejszą wyporność. Kutry należące do spółdzielni zostały również zredukowane. Po 1995 r. dane odnoszą się tylko do floty PPiUR „Szkuner” we Władysławowie, który przetrwał jako jedyny z państwowych podmiotów eksploatujących flotę kutrową.

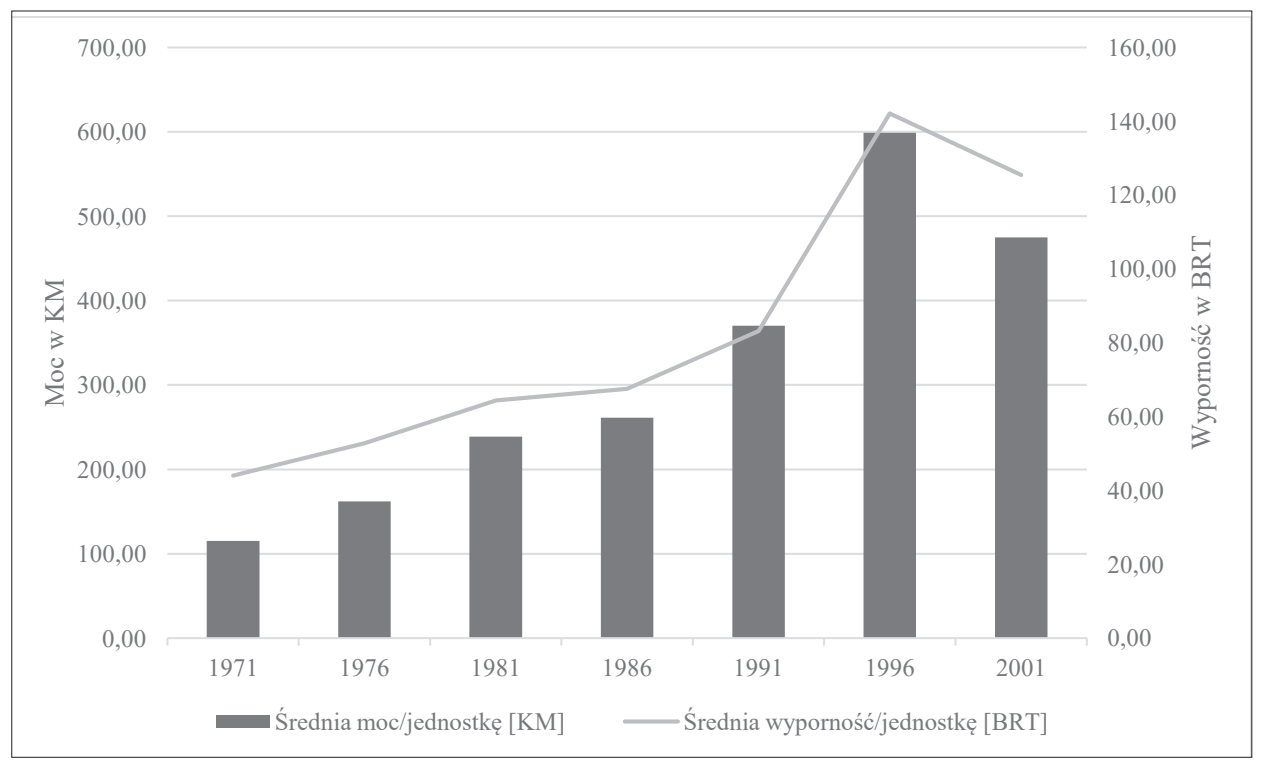

Rys. 3. Średnia moc [KM] oraz średnia wyporność [BRT] polskiej, państwowej floty kutrowej eksploatowanej na Morzu Bałtyckim w latach 1971-2001

Źr ódło: opracowanie własne na podstawie: Gospodarka rybna w latach 1971-1996. Materiały do badań, „Studia i Materiały MIR”, Seria E, Nr 38, 40, 43-45, 47-50, 52, 53, 56, 57, Gdynia 1978-1998; Rybołówstwo polskie 1996-2002, „Studia i Materiały MIR”, Seria E, Nr 55, 58, 59, 61, 63, 64, 66, Gdynia 1998-2004.

${ }^{38}$ Ewolucja floty kutrowej znajdującej się w eksploatacji państwowych armatorów na Morzu Bałtyckim miała swoje odzwierciedlenie we wzroście pojemności poszczególnych jednostek. Przykładowo jednostki typu B-25s miały wyporność 106 GT przy pojemności ładowni $80 \mathrm{~m}^{3}, \mathrm{~KB}-21$ wyporność 79 GT przy pojemności ładowni $60 \mathrm{~m}^{3}$, KŁ-21 pojemność ładowni $40 \mathrm{~m}^{3}$ przy identycznej wyporności, B-25s/A wyporność 106 GT przy pojemności ładowni $80 \mathrm{~m}^{3}$, B-410 wyporność 115 GT przy pojemności ładowni 97,5 m³, B-403 wyporność 130 GT przy pojemności ładowni $100 \mathrm{~m}^{3}$, B-280 wyporność 175,6 GT przy pojemności ładowni $140 \mathrm{~m}^{3}$, TMC-001 wyporność 145 GT (Dane na podstawie: W. Blady, Polska flota rybacka..., s. $66,74-77,82-86)$. 
Wraz z postępującymi tendencjami modernizacyjnymi oraz zmniejszaniem się liczby kutrów stopniowo zwiększała się średnia moc silników. Jej główną przyczyną było wprowadzenie do służby jednostek typu B-25s/A wyposażonych w maszyny Wola-Henschel 22H12A o mocy $350 \mathrm{KM}$, a w okresie późniejszym jednostek typu B-410 oraz B-403, posiadających silniki Sulzer-Cegielski 6AL20/24 o mocy $570 \mathrm{KM}^{39}$. Dodatkowym uzupełnieniem państwowej floty kutrowej były kutry KB-21 i KŁ-21 przeznaczone dla spółdzielni, które przyczyniły się do wzrostu średniej mocy floty, posiadając napędy główne (ZMIN-Wola H12) o mocy $310 \mathrm{KM}^{40}$. Analogicznie do przeprowadzonej wcześniej analizy mocy identyczne wnioski nasuwają się, gdy weźmiemy pod uwagę średnią wyporność. Pierwszym bodźcem wzrostu było uzupełnienie floty jednostkami o większej wyporności (B-25s/A, B-410, B-403), co wpłynęło na powolny przyrost badanej zmiennej. Wraz z wycofaniem ze służby pod koniec lat osiemdziesiątych XX w. mniejszych kutrów burtowych, ponownie wzrosła wyporność nominalna kutrów. Po przekształceniach dotyczyła ona początkowo dwóch państwowych przedsiębiorstw, a finalnie tylko PPiUR „Szkuner” we Władysławowie, czego odzwierciedleniem jest widoczny spadek zmiennej ${ }^{41}$.

\section{Połowy polskiej państwowej floty kutrowej na Morzu Bałtyckim w latach 1971-2001}

Kolejnym elementem analizy podjętym w artykule są połowy uzyskiwane przez państwowych armatorów eksploatujących kutry na Morzu Bałtyckim. Osiągane w oparciu o jego łowiska wyniki cechowały się w badanym okresie dużą zmiennością, która była uzależniona od wielu czynników. Przyjmując najbardziej przejrzystą systematykę można je podzielić na techniczne

39 Ibidem, s. 82.

40 Ibidem, s. 74.

41 W latach 1994-2001 łączna moc państwowej floty kutrowej na Morzu Bałtyckim ulegała dużym wahaniom. W 1994 r. wynosiła ona 2280 KM, w 1995 r. - 2850 KM (co wynikało z włączenia się do połowów przedsiębiorstwa „Dalmor-Bałtyk” Sp. z o.o.), 1996 r. - 4790 KM, 1997 r. - 4790 KM (był to efekt zwiększenia się floty pozostającej w eksploatacji PPiUR „Szkuner” oraz zwiększenia floty spółki „Dalmor-Bałtyk”), w 1998 r. - 2850 KM (wycofanie się spółki „Dalmor-Bałtyk”) i od tego roku wartość do końca badanego okresu pozostała niezmienna (AEK MIR, Analiza ekonomiczna rybołówstwa morskiego za 1995 rok, red. S. Szostak, G. Aguirre, J. Grzenia i inni, Gdynia 1996, [maszynopis niepublikowany], s. 26; Rybołówstwo polskie 1996, „Studia i Materiały MIR”, Seria E, Nr 55, red. S. Szostak, E. Kuzebski, B. Pieńkowska i inni, Gdynia 1998, s. 34; Rybołówstwo polskie 1997, „Studia i Materiały MIR”, Seria E, Nr 58, red. S. Szostak, E. Kuzebski, B. Pieńkowska i inni, Gdynia 1999, s. 33; Rybołówstwo polskie 1998..., s. 22; Rybołówstwo polskie 1999, „Studia i Materiały MIR”, Seria E, nr 61, red. S. Szostak, E. Kuzebski, B. Pieńkowska i inni, Gdynia 2001, s. 23-24). 
i biologiczne. 0 ile te pierwsze polegają głównie na utrzymaniu floty w technicznej gotowości oraz modernizacji jej składu i wyposażenia, to drugie są całkowicie niezależne. Do najważniejszych aspektów biologicznych należy włączyć wydajność oraz warunki meteorologiczne ${ }^{42}$. Połączenie to razem tworzy okoliczności, w których flota kutrowa prowadziła połowy. Dane za lata 1971-1989 zaprezentowano na rysunku 4.

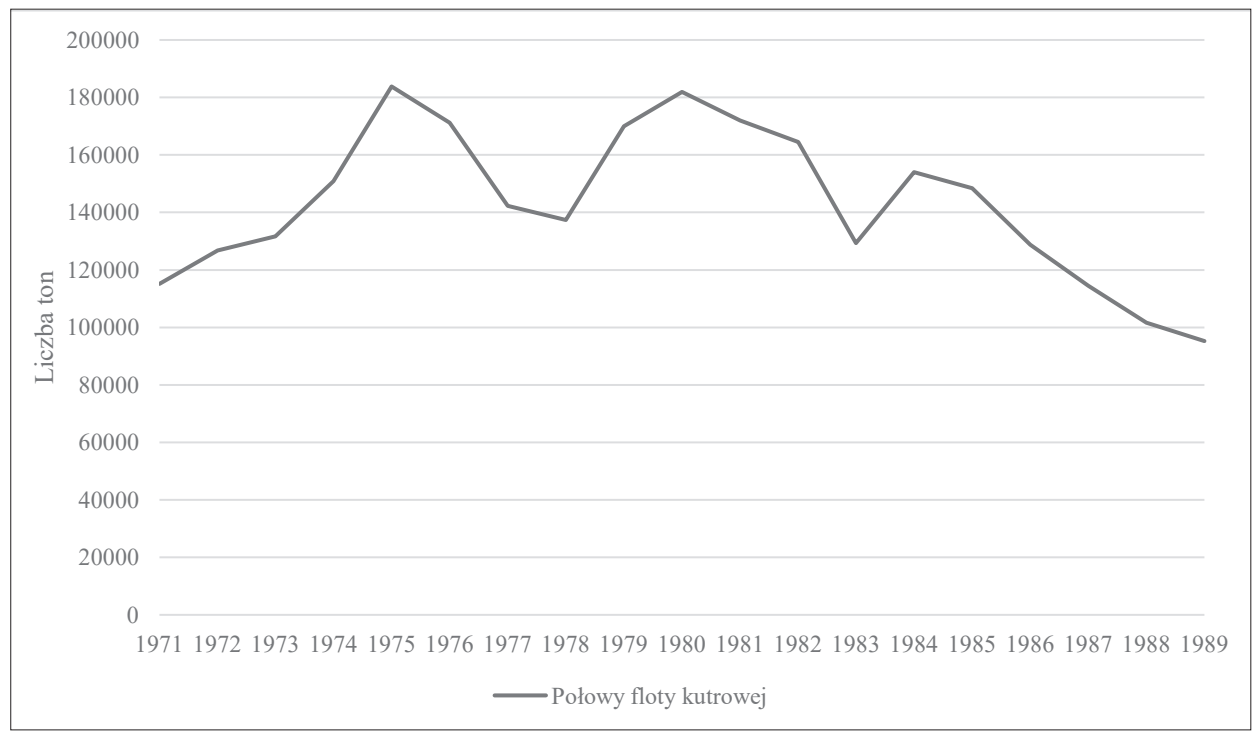

Rys. 4. Połowy polskiej, państwowej floty kutrowej na Morzu Bałtyckim w latach 1971-1989 [t] Źródło: Opracowanie własne na podstawie: Gospodarka rybna w latach 1971-1989. Materiały do badań, „Studia i Materiały MIR”, Seria E, Nr 38, 40, 43-45, 47-49, Gdynia 1978-1991.

Rozpatrując połowy uzyskane przez państwową flotę kutrową na Morzu Bałtyckim, nasuwa się kilka wniosków. Podjęta w połowie lat siedemdziesiątych XX w. druga modernizacja floty polegająca na wprowadzeniu do służby jednostek typu B-25s/A miała odzwierciedlenie w realnych wynikach ${ }^{43}$.

${ }^{42}$ Dodatkowy aspekt związany z technicznym utrzymaniem floty to wydajność pracy zatrudnionych osób.

${ }^{43} \mathrm{~W}$ ramach drugiej fazy modernizacji polskiej, państwowej floty kutrowej na Morzu Bałtyckim do służby wprowadzono następujące jednostki typu B-25s/A: dla PPiUR „Koga” w Helu - Hel-137, Hel-138 (1973 r.), Hel-139, Hel-140, Hel-141 (1974 r.), Hel-142, Hel-143, Hel-144, Hel-145 (1975 r.); dla PPiUR „Szkuner” we Władysławowie - Wła-202, Wła-203 (1972 r.), Wła-204, Wła-205, Wła-206 (1973 r.), Wła-200, Wła-201, Wła-207, Wła-208, Wła-209, Wła-210, Wła-211 (1974 r.), Wła-212 (1975 r.); dla PPiUR „Korab” w Ustce - Ust-97, Ust-98 (1971 r.), Ust-94, Ust-95, Ust-96, Ust-102 (1972 r.), Ust-90, Ust-91, Ust-92, Ust-93 (1973 r.), Ust-88, Ust-89 (1974 r.); dla PPiUR „Kuter” w Darłowie - Dar-157, Dar-158, Dar159, Dar-160 (1973 r.), Dar-161, Dar-162, Dar-163, Dar-164 (1974 r.), Dar-165, Dar-166, Dar-167, Dar-168, Dar-169, Dar-170 (1975 r.); dla PPiUR „Barka” w Kołobrzegu - Koł-163, 
Za szczytowy moment należy uznać rok 1975, kiedy polskie, państwowe kutry na Morzu Bałtyckim uzyskały łącznie prawie 184 tys. ton surowca ${ }^{44}$.

Z okresem masowej implementacji jednostek typu B-410, a później także B-403 związany był spadek połowów, gdzie za najsłabszy należy uznać 1978 r. ${ }^{45}$ Później, postępująca modernizacja floty wywarła swój wpływ na rzeczywiste wyniki połowowe uzyskiwane przez kutry. Analizując dane zawarte na rysunku 4 uwidoczniło się drugie silne załamanie przypadające na 1983 r., kiedy rzeczywisty wpływ na wyniki floty kutrowej miały złe warunki meteorologiczne ${ }^{46}$. W 1984 r. uzyskano ponownie większą ilość połowów, ale wpłynął na nie dalszy spadek wydajności, gdzie za moment krytyczny należy uznać 1989 r., kiedy państwowa flota kutrowa na Morzu Bałtyckim nie przekroczyła granicy 100 tys. ton połowów w skali roku ${ }^{47}$.

Rozpoczęty w 1990 r. proces prywatyzacji państwowego rybołówstwa znalazł swoje odzwierciedlenie $w$ wynikach połowowych floty kutrowej. Oddawanie $\mathrm{w}$ leasing jednostek uznanych przez państwowe zarządy za wyeksploatowane przyczynił się do stopniowego obniżenia łącznego wolumenu uzyskanego surowca ${ }^{48}$. Uwidoczniło się to zwłaszcza na przestrzeni

Koł-164, Koł-165, Koł-166 (1972 r.), Koł-167, Koł-168, Koł-169, Koł-170 (1973 r.), Koł-171, Koł-172 (1974 r.); dla SPRM „Jedność Rybacka” w Gdańsku - Gda-16, Gda-17, Gda-20, Gda-21 (1975 r.) (W. Blady, Polska flota rybacka..., s. 75).

${ }^{44}$ Gospodarka rybna w latach 1974-1976..., s. 143.

45 Jedną z przyczyn załamania połowów było przesunięcie części jednostek do połowów dorsza, które należało uznać za bardziej ukierunkowane. Dodatkowo dały o sobie znać słabsze warunki meteorologiczne związane ze zbliżającą się tzw. zimą stulecia. Spadek połowów dotyczył w większym stopniu przedsiębiorstw państwowych niż spółdzielni, których wyniki nieznacznie wzrosły (Gospodarka rybna w latach 1977-1979..., s. 111).

${ }^{46}$ W 1983 r. na Morzu Bałtyckim miało miejsce wiele sztormów. Przyczyniły się one do widocznego spadku dni połowowych jednostek względem postojowych. Przykładowo w PPiUR „Koga” liczba dni postojowych względem połowowych wzrosła następująco: dla jednostek B-25s w 1982 r. postojowych 1478, połowowych 2632 w 1983 r. postojowych 2220, połowowych 928, B-25s/A w 1982 r. postojowych 801, połowowych 1490, w 1983 r. postojowych 928, połowowych 1283, dla jednostek typu B-410 w 1982 r. postojowych 467, połowowych 1052, w 1983 r. postojowych 770, połowowych 1049 (Gospodarka rybna w latach 1981-1983..., s. 127-145).

47 Spadek połowów wynikał z ograniczenia gotowości technicznej starzejącej się floty oraz obniżenia wydajności biomasy dorsza, która była głównym przedmiotem połowów państwowych kombinatów. Dodatkowo Zygmunt Polański i Zdzisław Russek wskazali na wadliwą strukturę organizacyjno-zarządczą gospodarki rybnej w omawianym okresie (AEK MIR, Z. Polański, Z. Russek, Propozycje i warunki przekształceń własnościowych w polskiej gospodarce rybnej /projekt wstępny/, Gdynia 1990, [maszynopis niepublikowany], s. 8-9).

${ }^{48} \mathrm{~W}$ pierwszej kolejności przekształcenia prywatyzacyjne dotyczyły jednostek 17-metrowych, burtowców B-25s oraz B-25s/A. Kutry oddawano w leasing lub dzierżawę w latach 1989-1991 (AEK MIR, S. Szostak, Z. Russek, Analiza ekonomiczno-finansowa Przedsiębiorstwa Połowów i Usług Rybackich „Koga” w Helu za lata 1988-1990 i pierwsze półrocze 1991 r., [brak miejsca i daty wydania, maszynopis niepublikowany], s. 7). 
lat 1991-1992, jednakże spadek wyników był związany ze zmniejszeniem się populacji dorsza, który przez państwowe kombinaty i spółdzielnie, ze względu na wysoką wartość, uznawany był za gatunek pierwszoplanowy, marginalizując pozostałe ${ }^{49}$.

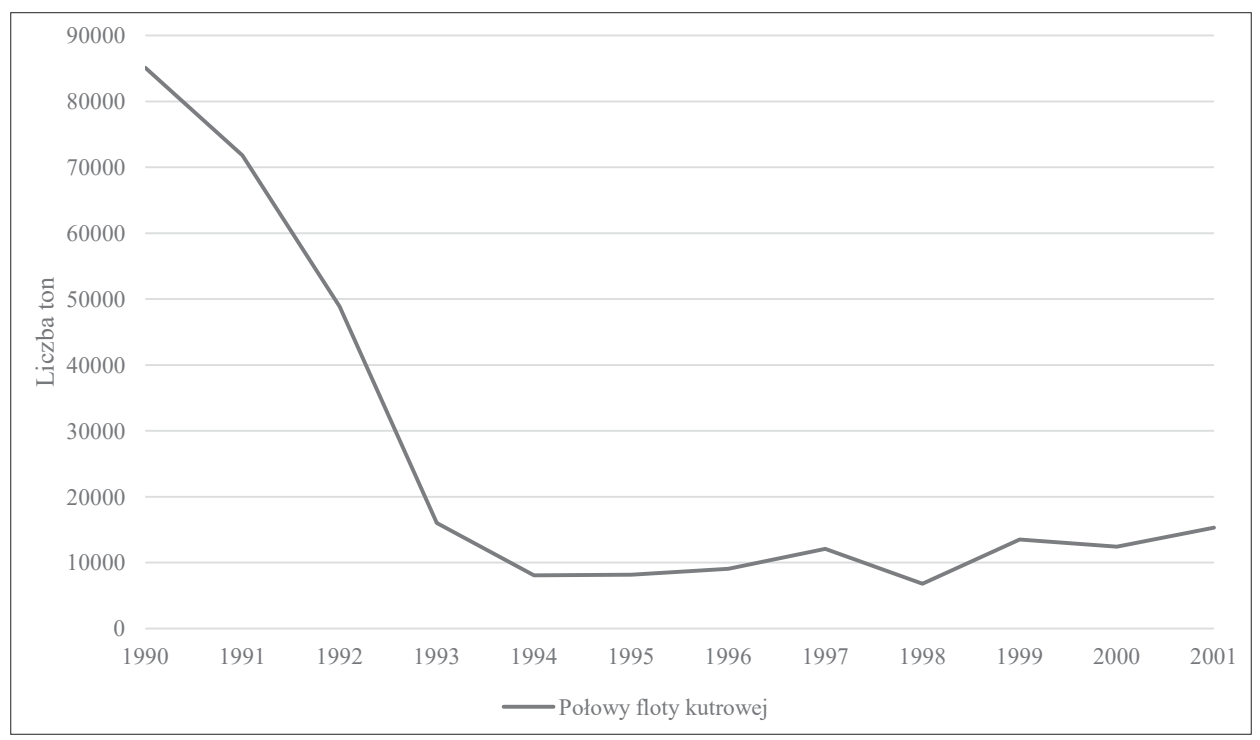

Rys. 5. Połowy polskiej, państwowej floty kutrowej na Morzu Bałtyckim w latach 1990-2001 [t] Źródło: Opracowanie własne na podstawie: Gospodarka rybna w latach 1990-1996, „Studia i Materiały MIR", Seria E, Nr 50, 52, 53, 56, 57, Gdynia 1994-1998; Rybołówstwo polskie 1996-2002, „Studia i Materiały MIR”, Seria E, nr 55, 58, 59, 61, 63, 64, 66, Gdynia 1998-2004.

Wraz z postępującym procesem przekształceń w strukturze własności zmniejszał się wolumen połowów. Za moment szczytowy należy uznać lata 1992-1994, kiedy przedsiębiorstwa rozpoczęły wyzbywać się nowocześniejszych jednostek, do których należało zaliczyć kutry rufowe. Wyjątkiem pozostał PPiUR „Szkuner”, który jako jedyne przedsiębiorstwo od 1997 r. prowadziło samodzielnie połowy na Morzu Bałtyckim ${ }^{50}$. Po 1994 r. nie cechowały się one wysoką efektywnością, jednakże wpływ na ich wzrost

${ }^{49}$ Analizując połowy szprota i śledzia w latach 1989-1992, nasuwają się następujące wnioski. Ani przedsiębiorstwa państwowe, ani spółdzielnie nie wykorzystywały nawet w 50 procentach przyznanych im limitów połowowych. Wynikało to z ukierunkowania flot na uzyskiwanie dorsza, cechującego się o wiele wyższą wartością.

${ }^{50} \mathrm{~W}$ przypadku PPiUR „Szkuner” nie dokonano rozdziału majątku wyzbywając się tylko elementów nieprodukcyjnych. Całość majątku związanego z produkcją została skonsolidowana w rękach przedsiębiorstwa. Nie zrezygnowano z eksploatacji floty. Okoliczności te pozwoliły przetrwać „Szkunerowi” okres transformacji. 
przypadający na lata 1996-1997 miało powołanie do życia spółki „DalmorBałtyk" Sp. z o.o., która eksploatowała dwie jednostki ${ }^{51}$. Najsłabsze wyniki w post-transformacyjnej rzeczywistości przypadły na 1998 r., kiedy jednostki należące do ostatniego państwowego podmiotu nie przekroczyły 7 tys. ton w skali roku. Lata następne cechowały się dalszym wzrostem połowów i efektywności, co pozwoliło zachować „Szkunerowi” stabilną pozycję na rynku.

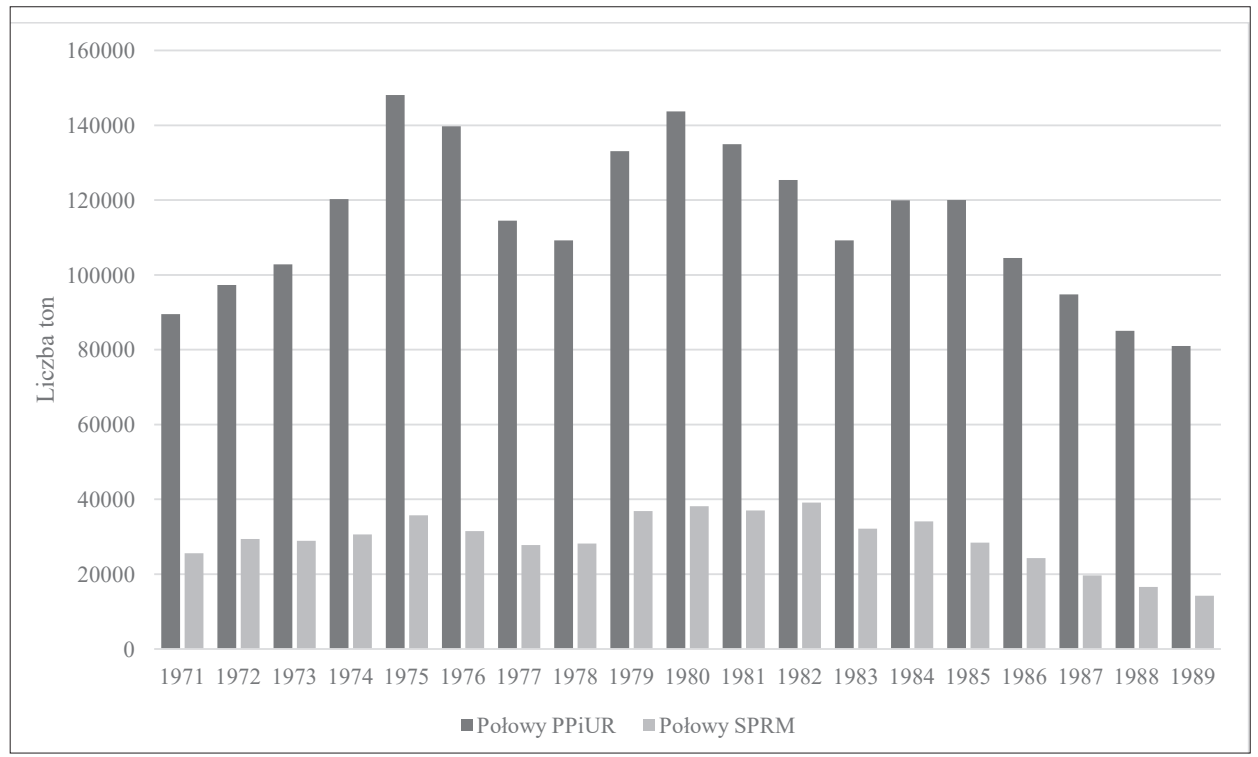

Rys. 6. Połowy jednostek znajdujących się w eksploatacji PPiUR i SPRM w latach 1971-1989 [t] Źr ó dło: Opracowanie własne na podstawie: Gospodarka rybna w latach 1971-1989. Materiały do badań, „Studia i Materiały MIR”, Seria E, nr 38, 40, 43, 44, 45, 47, 48, 49, Gdynia 1978-1991.

W celu zachowania pełnej przejrzystości analizy funkcjonowania państwowych podmiotów eksploatujących kutry na Morzu Bałtyckim należy rozdzielić realizowane przez nie połowy. Jak wynika z danych zamieszczonych na rysunku 6, o wiele wyższą aktywność wykazywała flota znajdująca się w eksploatacji przedsiębiorstw państwowych. Wynikało to z jej

51 Zgodnie z zachowanymi informacjami spółka „Dalmor-Bałtyk” została wydzielona z Przedsiębiorstwa Połowów Przetwórstwa i Handlu „Dalmor” SA w sierpniu 1995 r. Całościowy pakiet akcji spółki znajdował się w rękach „Dalmoru”. Do podstawowych zadań podmiotu należała eksploatacja łowisk bałtyckich przy wykorzystaniu floty kutrowej. Według stanu na 1996 r. zatrudniała 19 osób i planowano dalszy rozwój. W rezultacie braku pozytywnych wyników finansowych z działalności tej zrezygnowano (AEK MIR, E. Kuzebski, Ocena efektów ekonomicznych zmian strukturalnych i własnościowych w państwowych przedsiębiorstwach połowowych, Gdynia 1996, [maszynopis niepublikowany], s. 25). 
liczebności (do 1990 r. w jej skład wchodziło zawsze o około 100 kutrów więcej niż w SPRM) oraz z poczynionych unowocześnień i uzupełnień ${ }^{52}$. W rezultacie flota znajdująca się w eksploatacji SPRM posiadała o wiele niższą efektywność połowową. Istotnie jednostki należące do własności spółdzielczej cechowały się mniejszymi stopniem zmodernizowania.

Badanie wielkości połowowych uzyskiwanych przez pięć państwowych kombinatów wymaga wprowadzenia teoretycznego podziału przedsiębiorstw. Spośród nich największe floty połowowe znajdowały się w eksploatacji PPiUR „Szkuner” oraz PPiUR „Barka”, które w latach 1971-1990 posiadały w swojej eksploatacji średnio 49 oraz 44 jednostki rocznie. Do przedsiębiorstw o średniej wielkości należy zaliczyć PPiUR „Korab” oraz PPiUR „Kuter” będące armatorami dla odpowiednio uśredniając 41 jednostek rocznie. Najmniejszym przedsiębiorstwem wśród prezentowanej grupy było PPiUR „Koga” eksploatujące średniorocznie 30 jednostek pływających. Należy zwrócić uwagę, że jest to podział teoretyczny i wskazuje tylko uśredniony stan posiadania armatorów.

W przypadku uzyskiwanych, przez poszczególne segmenty państwowej gospodarki rybnej, wyników połowowych należy nadmienić, że przedsiębiorstwom państwowym do 1973 r. nie udało się przekroczyć pułapu rocznych połowów w granicach 100 tys. ton ${ }^{53}$. Lata następne cechowały się wzrostem badanej zmiennej, który następował ustawicznie do 1975 r., co było niewątpliwie związane z wprowadzaniem do eksploatacji nowych kutrów typu B-25s/A. W kolejnych latach doszło do spadku połowów analogicznego do danych prezentowanych na rysunku 5. Następny okres cechował się dalszym wzrostem pozyskiwania surowca, co było powiązane z wdrożeniami do służby nowych jednostek. Od około 1980 r. uwidocznił się spadek efektywności, gdzie najniższa wartość przypadła na 1983 r. Niemal porównywalne były wyniki uzyskane w 1984 i 1985 r., kiedy państwowe przedsiębiorstwa eksploatujące kutry uzyskały łącznie około 120 tys. ton surowca ${ }^{54}$. Pomimo podjętych prac modernizacyjnych kombinaty połowowe od $1986 \mathrm{r}$. notowały dalszy spadek połowów, gdzie za najniższe należy uznać te uzyskane w 1988 i 1989 r.

Zupełnie inna sytuacja miała miejsce, gdy dokonamy analizy składów flot spółdzielni rybackich zajmujących się eksploatacją kutrów. Pierwszy wniosek dotyczy o wiele mniejszej liczebności jednostek we flotach względem przedsiębiorstw państwowych. Do SPRM, które cechowały się ich wysoką liczbą należy zaliczyć „Gryf” we Władysławowie, „Rybmor” w Łebie oraz

\footnotetext{
52 Mowa tutaj o opisanych wcześniej uzupełnieniach i modernizacjach floty.

53 Gospodarka rybna w latach 1973-1975..., s. 124.

${ }^{54}$ Gospodarka rybna w latach 1983-1985..., s. 141.
} 
„Belonę” w Dziwnowie, które w okresie 1971-1990 średniorocznie posiadały w eksploatacji odpowiednio 21 kutrów, 17 kutrów i 16 kutrów. Do średnich spółdzielni należały gdańska „Jedność Rybacka”, „Bałtyk” w Kołobrzegu oraz „Łosoś” w Ustce eksploatujące 11 kutrów, 8 kutrów oraz 7 kutrów w ujęciu średniorocznym w całym badanym okresie. Pozostałe podmioty to SPRM posiadające floty o mieszanej strukturze kutrowo-łodziowej, nie cechujące się wysokim wykorzystaniem tych pierwszych w globalnych połowach na Morzu Bałtyckim ${ }^{55}$.

Odnośnie do wyników połowowych były one niemal analogiczne, aczkolwiek o wiele mniejsze. Do 1973 r. nie przekroczyły 30 tys. ton rocznie, ale ich wzrosty i spadki były zbliżone do połowów państwowych kombinatów. Przykład to zwyżka przypadająca na lata 1974-1976, gdzie za najlepszy należało uznać rok $1975^{56}$. Kolejne lata przyniosły spadek w uzyskiwaniu surowca, aczkolwiek jako najsłabszy należało uznać, w przeciwieństwie do przedsiębiorstw państwowych, 1977 r. Za szczytowy moment funkcjonowania SPRM w ramach gospodarki rybnej należy uznać początek lat osiemdziesiątych XX w., kiedy łączny wolumen oscylował w granicach 40 tys. ton w skali roku ${ }^{57}$. Nieustannie od 1985 r. odczuwalny był spadek połowów, który był związany ze zmniejszającą się wydajnością pracy i łowisk bałtyckich ${ }^{58}$.

\section{Tabela 3}

Udział poszczególnych państwowych przedsiębiorstw w połowach na Morzu Bałtyckim w latach 1971-1989 [\%]

\begin{tabular}{|c|c|c|c|c|c|}
\hline Rok & $\begin{array}{c}\text { PPiUR } \\
\text { „Koga }\end{array}$ & $\begin{array}{c}\text { PPiUR } \\
\text { „Szkuner” }\end{array}$ & $\begin{array}{c}\text { PPiUR } \\
\text { „Korab” }\end{array}$ & $\begin{array}{c}\text { PPiUR } \\
\text { „Kuter” }\end{array}$ & $\begin{array}{c}\text { PPiUR } \\
\text { „Barka” }\end{array}$ \\
\hline 1971 & 16,45 & 26,08 & 18,63 & 17,69 & 21,14 \\
\hline 1972 & 17,72 & 26,02 & 17,99 & 17,60 & 20,66 \\
\hline 1973 & 17,08 & 24,21 & 19,66 & 18,42 & 20,62 \\
\hline
\end{tabular}

${ }^{55}$ Analogiczne uśrednione wielkości eksploatowanych flot $\mathrm{w}$ badanym okresie prezentują się następująco: SPRM „Ławica” w Darłowie - 3 jednostki rocznie, SPRM „Wyzwolenie” w Świbnie - 1 jednostka rocznie.

${ }^{56}$ Gospodarka rybna w latach 1974-1976..., s. 143.

57 Duży wpływ na wzrost połowów miały wprowadzone do służby 4 kutry rufowe typu B-410, które zasiliły flotę SPRM „Bałtyk” w Kołobrzegu (Gospodarka rybna w latach 1979-1981..., s. 160; Gospodarka rybna w latach 1981-1983..., s. 147).

${ }^{58}$ AEK MIR, Z. Polański, Sytuacja polskiego rybołówstwa na Bałtyku. Nakład połowowy, połowy, efekty, limity, Gdynia 1991, [maszynopis niepublikowany], s. 1. 
Tabela 3 cd.

\begin{tabular}{|c|c|c|c|c|c|}
\hline Rok & $\begin{array}{c}\text { PPiUR } \\
\text { „Koga }\end{array}$ & $\begin{array}{c}\text { PPiUR } \\
\text { „Szkuner” }\end{array}$ & $\begin{array}{c}\text { PPiUR } \\
\text { „Korab” }\end{array}$ & $\begin{array}{c}\text { PPiUR } \\
\text { „Kuter” }\end{array}$ & $\begin{array}{c}\text { PPiUR } \\
\text { "Barka” }\end{array}$ \\
\hline 1974 & 16,55 & 25,02 & 21,38 & 17,64 & 19,41 \\
\hline 1975 & 15,31 & 23,85 & 20,29 & 18,00 & 22,56 \\
\hline 1976 & 16,50 & 25,08 & 18,12 & 19,97 & 20,32 \\
\hline 1977 & 15,05 & 25,09 & 20,23 & 19,23 & 20,40 \\
\hline 1978 & 17,15 & 22,81 & 21,76 & 17,30 & 20,98 \\
\hline 1979 & 14,58 & 24,87 & 20,89 & 17,15 & 22,50 \\
\hline 1980 & 15,02 & 26,84 & 20,23 & 16,60 & 21,30 \\
\hline 1981 & 16,82 & 28,65 & 18,62 & 17,18 & 18,74 \\
\hline 1982 & 14,56 & 25,46 & 20,50 & 18,82 & 20,66 \\
\hline 1983 & 12,24 & 28,58 & 20,73 & 18,34 & 20,11 \\
\hline 1984 & 12,70 & 29,26 & 19,94 & 17,44 & 20,66 \\
\hline 1985 & 13,28 & 28,78 & 18,06 & 16,81 & 23,06 \\
\hline 1986 & 11,68 & 27,44 & 20,31 & 17,69 & 22,89 \\
\hline 1987 & 11,66 & 26,99 & 22,22 & 19,42 & 19,71 \\
\hline 1988 & 10,44 & 26,15 & 22,98 & 17,89 & 22,55 \\
\hline 1989 & 9,87 & 24,55 & 20,73 & 19,49 & 25,36 \\
\hline
\end{tabular}

Źr ódło: Opracowanie własne na podstawie: Gospodarka rybna w latach 1971-1989. Materiały do badań, „Studia i Materiały MIR”, Seria E, Nr 38, 40, 43-45, 47-49, Gdynia 1978-1991.

Omówienia wymagają dane dotyczące udziału poszczególnych przedsiębiorstw państwowych w łącznych połowach na Morzu Bałtyckim wskazane w tabeli 3. Zgodnie z wcześniejszymi ustaleniami najwyższe wyniki były uzyskiwane w pierwszej kolejności przez PPiUR „Szkuner” we Władysławowie oraz PPiUR „Barka” w Kołobrzegu. Na następnych miejscach uplasowały się PPiUR „Kuter” w Darłowie oraz PPiUR „Korab” w Ustce. Najniższe rezultaty uzyskała w badanym okresie flota znajdująca się w eksploatacji PPiUR „Koga” w Helu. Należy zwrócić uwagę, że wpływ na wyniki miały: liczebność flot, ich skład oraz polityka firmy polegająca na ukierunkowaniu połowów poszczególnych gatunków ryb ${ }^{59}$.

${ }^{59} \mathrm{~W}$ okresie realizacji założeń gospodarki centralnie planowanej jednostki eksploatowane przez państwowe podmioty prowadziły głównie ukierunkowane połowy dorsza. Wyni- 


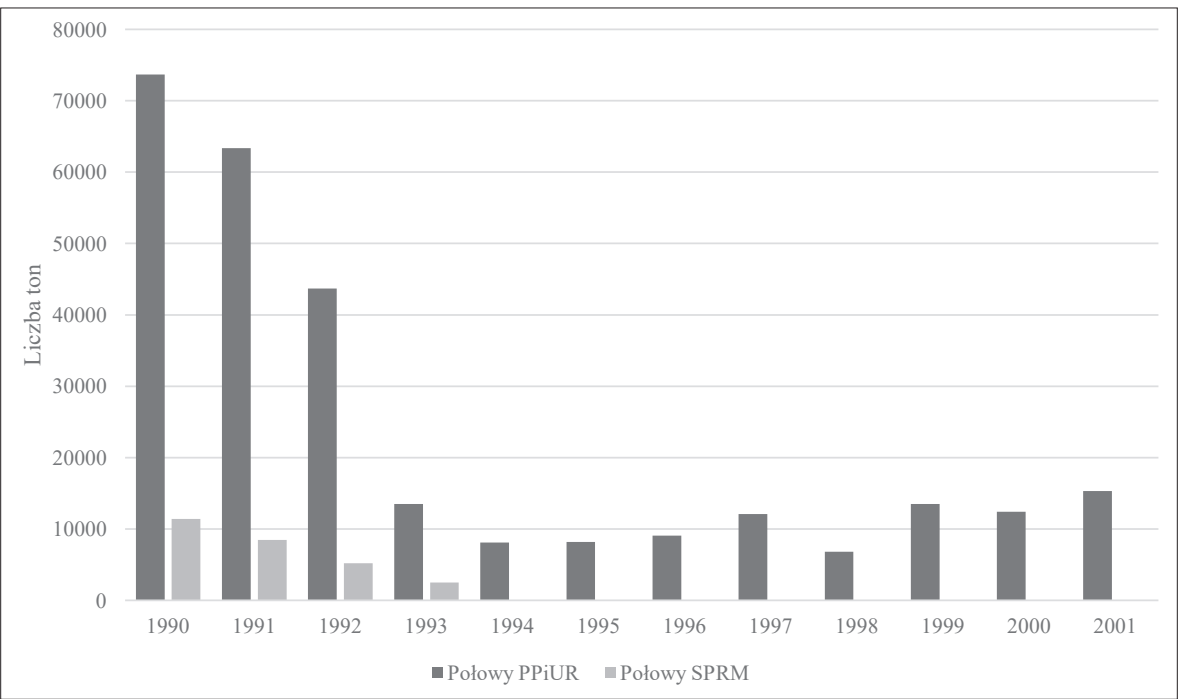

Rys. 7. Połowy jednostek znajdujących się w eksploatacji PPiUR i SPRM w latach 1990-2001 [t] Źródło: Opracowanie własne na podstawie: Gospodarka rybna w latach 1990-1996, „Studia i Materiały MIR", Seria E, nr 50, 52, 53, 56, 57, Gdynia 1994-1998; Rybołówstwo polskie 1996-2002, „Studia i Materiały MIR”, Seria E, nr 55, 58, 59, 61, 63, 64, 66, Gdynia 1998-2004.

Rozpoczęcie przekształceń prywatyzacyjnych miało swoje odzwierciedlenie w połowach państwowej floty kutrowej wskazanych na rysunku 7. Od 1990 r. cechowały się stałym spadkiem, który był związany z rezygnacją z eksploatacji jednostek uznanych przez przedsiębiorstwa za nierentowne, a więc głównie kutrów burtowych. Dodatkowo dały o sobie znać problemy z utrzymaniem pozostawionej w eksploatacji floty, gdzie do decydujących czynników należało włączyć zaopatrzenie w paliwo. Za przełomowe należało uznać lata 1992-1994, kiedy wszystkie przedsiębiorstwa poza PPiUR „Szkuner” zrezygnowały z eksploatacji floty. Sytuacja ta miała wpływ na realne wyniki połowowe, będące na początku badanego okresu o wiele niższe niż w okresie gospodarki centralnie planowanej. Ustawicznie malejąc, osiągnęły w 1992 r. poziom ponad 42 tys. ton, co nie stanowiło nawet 50 procent tych uzyskanych w 1989 r. Rezygnacja z wykorzystania floty spowodowała, że państwowe kombinaty ograniczyły swoją rolę, co wpłynęło na ich pozycję rynkową, która znacząco osłabła ${ }^{60}$.

kało to z wysokiego popytu krajowego, a w okresie późniejszym przypadającym na koniec lat osiemdziesiątych XX w. z możliwości zdawania nieoprawionych ryb dla duńskich odbiorców za granicą. Pozostałe gatunki nie cieszyły się zainteresowaniem państwowych podmiotów (AEK MIR, Modernizacja przetwórstwa rybnego z połowów bałtyckich, red. Z. Polański, A. Brzyski, P. Bykowski i inni, Gdynia 1991, [maszynopis niepublikowany], s. 4).

${ }^{60}$ S. Szostak, Polskie rybołówstwo w latach 1990-1995..., s. 8. 
Analogiczna sytuacja miała miejsce w przypadku floty znajdującej się w eksploatacji SPRM. Rezygnacja z połowów przez poszczególnych armatorów przypadła na lata 1989-1992. Wtedy też działalność była stopniowo ograniczana. Na niewielką skalę kontynuowano ją przez SPRM „Bałtyk” w latach 1993-1994, która eksploatowała jeden kuter typu B-280. Finalnie została zakończona około $1995 \mathrm{r}$.

\section{Tabela 4}

Udział poszczególnych państwowych przedsiębiorstw w połowach na Morzu Bałtyckim w latach 1990-1995 [\%]

\begin{tabular}{|c|c|c|c|c|c|}
\hline Rok & $\begin{array}{c}\text { PPiUR } \\
\text { „Koga" }\end{array}$ & $\begin{array}{c}\text { PPiUR } \\
\text { „Szkuner" }\end{array}$ & $\begin{array}{c}\text { PPiUR } \\
\text { „Korab" }\end{array}$ & $\begin{array}{c}\text { PPiUR } \\
\text { „Kuter" }\end{array}$ & $\begin{array}{c}\text { PPiUR } \\
\text { "Barka" }\end{array}$ \\
\hline 1990 & 7,63 & 25,49 & 21,79 & 17,43 & 27,66 \\
\hline 1991 & 14,98 & 18,03 & 22,26 & 15,24 & 29,49 \\
\hline 1992 & 6,66 & 16,36 & 27,33 & 16,25 & 33,40 \\
\hline 1993 & 0,00 & 34,44 & 18,24 & 13,05 & 34,27 \\
\hline 1994 & 0,00 & 99,51 & 0,00 & 0,00 & 0,49 \\
\hline 1995 & 0,00 & 100,00 & 0,00 & 0,00 & 0,00 \\
\hline
\end{tabular}

Źr ód ło: Opracowanie własne na podstawie: Gospodarka rybna w latach 1990-1996, „Studia i Materiały MIR", Seria E, nr 50, 52, 53, 56, 57, Gdynia 1994-1998.

Transformacja polskiego, państwowego rybołówstwa na Morzu Bałtyckim przyczyniła się do zmniejszenia udziału kombinatów w eksploatacji łowisk. Pomimo rozpoczęcia procesu transformacji niemal niezmienne pozostały pozycje poszczególnych przedsiębiorstw. Nadal do grupy najsilniejszych należało zaliczyć PPiUR „Barka” oraz PPiUR „Szkuner”. W momencie wyzbycia się przez przedsiębiorstwa większości jednostek dominująca rola przypadła PPiUR „Szkuner”, aczkolwiek względem całości bałtyckich połowów wartość ta była niewielka ${ }^{61}$.

${ }^{61}$ Na przestrzeni lat 1994-2001, PPiUR „Szkuner” uzyskał następujące wyniki połowowe: 1995 r. -8173 t, 1996 r. -9074 t, 1997 r. -12100 t, 1998 r. -6800 t, 1999 r. -13500 t, 2000 r. - 12400 t, 2001 r. - 15300 t (Gospodarka rybna w latach 1994-1996, „Studia i Materiały MIR”, Seria E, nr 57, red. J. Grzenia, E. Makowiecka, H. Wołoszyk, Gdynia 1998, s. 40; Rybołówstwo polskie 1997..., s. 10; Rybołówstwo polskie 1998..., s. 8; J. Zieziula, Polska gospodarka rybna w okresie transformacji (1990-2001). Teoria i praktyka, Gdynia 2002, s. 57; Rybołówstwo pol- 
Ważne z punktu widzenia ekonomiki eksploatacji floty jest zagadnienie wydajności osiąganej przez poszczególne jednostki burtowe. Szczegółowe wyniki zostały zaprezentowane $\mathrm{w}$ tabeli $5^{62}$. Pierwszym rodzajem jednostek, które tworzyły badaną kategorię były stalowe kutry burtowe określone w sprawozdawczości rybackiej jako „17 metrowe”. Jednostki te znajdowały się głównie w eksploatacji PPiUR „Korab”, „Kuter” i „Barka” i na przestrzeni badanego okresu były stopniowo wycofywane ze służby ${ }^{63}$. Osiągane wyniki oscylowały w granicy ponad 200 ton w skali roku, z odstępstwami przypadającymi na 1983 i 1985 r. Badanie uśrednionych wartości połowowych pozwala na wskazanie najwyższej efektywności przypadającej na $1979 \mathrm{r}$.

Drugim rodzajem jednostek burtowych znajdującym się w eksploatacji państwowych kombinatów były kompozytowe kutry typu B-12. Ich armatorami były cztery przedsiębiorstwa, a w swojej flocie nie posiadało ich tylko PPiUR „Korab” w Ustce. Ze względu na starszy rodowód i konstrukcję ich kasację „Kuter” i „Barka” rozpoczęły już na początku lat siedemdziesiątych XX w. ${ }^{64}$ Jako ostatnia została wycofana ze służby w 1977 r. para jednostek znajdująca się w eksploatacji PPiUR „Szkuner”. Na przestrzeni badanego okresu kutry typu B-12 osiągały zmienne wyniki połowowe. Do 1976 r. przekraczały nieznacznie średnio 300 ton w skali roku. Obniżenie przypadające na następne dwa lata było związane z planowaną kasacją.

Obok kompozytowych kutrów B-12, dużą grupę stanowiły kutry B-25 analogicznej konstrukcji. Ich głównymi armatorami były helska „Koga” oraz władysławowski „Szkuner”. Jednostki te zostały ostatecznie wycofane ze służby w 1979 r., co było powiązane z wprowadzaniem do linii trawlerów

skie 1999..., s. 9; Rybołówstwo polskie 2000, „Studia i Materiały MIR”, Seria E, Nr 63, red. S. Szostak, E. Kuzebski, B. Pieńkowska i inni, Gdynia 2002, s. 8; Rybołówstwo polskie 2001, „Studia i Materiały MIR", Seria E, nr 64, red. S. Szostak, E. Kuzebski, B. Pieńkowska, Gdynia 2003, s. 9; Rynek ryb stan i perspektywy, 2004, nr 1, red. J. Seremak-Bulge, S. Szostak, E. Kuzebski i inni, Warszawa 2005, s. 15).

${ }^{62} \mathrm{~W}$ tym przypadku przyjęto metodę badania uśrednionych wyników. Polegała ona na stworzeniu zbioru wszystkich kutrów danego typu i wyciągnięciu średniej arytmetycznej.

${ }^{63}$ Jako pierwszy proces kasacji rozpoczęły w 1973 r. PPiUR „Korab” i „Kuter”. W późniejszym okresie liczba „kutrów 17-m” sukcesywnie malała. Od 1983 r. flota „Korabia” zrezygnowała z ich eksploatacji. Identyczną decyzję w 1986 r. podjęto w darłowskim „Kutrze”. Ostatnią jednostkę prezentowanej kategorii wycofano z floty PPiUR „Barka” w 1993 r.

${ }^{64}$ Kasacja jednostek typu B-12 przebiegała następująco: w 1975 r. z eksploatacji tej klasy jednostek zrezygnowało PPiUR „Koga” w Helu, PPiUR „Szkuner” zrezygnowało w 1977 r., PPiUR „Kuter” zrezygnowało z eksploatacji wskazanych jednostek w 1974 r., PPiUR „Barka” wycofało ostatnie jednostki w 1971 r. (Gospodarka rybna w latach 1974-1976..., s. 118; Gospodarka rybna w latach 1975-1977..., s. 106). 
rufowych typu B-410 oraz B-403. Jak wynika z danych prezentowanych w tabeli 5, kutry B-25 uzyskiwały średnie wyniki w granicach 400 ton w skali roku w przeliczeniu na jednostkę.

\section{Tabela 5}

Uśrednione wyniki połowowe uzyskiwane na Morzu Bałtyckim przez kutry burtowe będące w eksploatacji PPiUR w latach 1971-1992 [t]

\begin{tabular}{|c|c|c|c|c|c|}
\hline \multirow{2}{*}{ Rok } & \multicolumn{5}{|c|}{ Typ kutra burtowego } \\
\cline { 2 - 6 } & Kuter 17m & B-12 & B-25 & B-25s & B-25s/A \\
\hline 1971 & 252,42 & 391,47 & 386,27 & 616,23 & 256,33 \\
\hline 1972 & 272,32 & 447,83 & 470,20 & 643,78 & 24,33 \\
\hline 1973 & 281,49 & 409,87 & 415,93 & 627,89 & 542,13 \\
\hline 1974 & 232,23 & 396,12 & 383,00 & 606,06 & 635,03 \\
\hline 1975 & 291,47 & 337,33 & 446,60 & 716,95 & 678,81 \\
\hline 1976 & 256,45 & 363,57 & 446,36 & 690,67 & 781,24 \\
\hline 1977 & 273,13 & 290,00 & 344,80 & 571,50 & 674,21 \\
\hline 1978 & 236,51 & 196,00 & 291,43 & 534,08 & 592,21 \\
\hline 1979 & 302,15 & - & 259,80 & 550,44 & 591,09 \\
\hline 1980 & 268,76 & - & - & 516,08 & 576,91 \\
\hline 1981 & 230,70 & - & - & 475,44 & 522,84 \\
\hline 1982 & 204,28 & - & - & 416,44 & 476,30 \\
\hline 1983 & 166,41 & - & - & 364,09 & 446,39 \\
\hline 1984 & 202,28 & - & - & 433,57 & 470,28 \\
\hline 1985 & 156,67 & - & - & 361,80 & 440,91 \\
\hline 1986 & 202,80 & - & - & 316,46 & 361,75 \\
\hline 1987 & 208,00 & - & - & 260,32 & 339,36 \\
\hline 1988 a & & - & - & 202,30 & 220,22 \\
\hline 1989 & - & - & - & 173,44 \\
\hline
\end{tabular}




\begin{tabular}{|c|c|c|c|c|c|}
\hline \multirow{2}{*}{ Rok } & \multicolumn{5}{|c|}{ Typ kutra burtowego } \\
\cline { 2 - 6 } & Kuter 17m & B-12 & B-25 & B-25s & B-25s/A \\
\hline 1990 & $\cdot$ & - & - & $\cdot$ & 105,00 \\
\hline 1991 & $\cdot$ & - & - & $\cdot$ & 9,00 \\
\hline 1992 & $\cdot$ & - & - & $\cdot$ & 88,14 \\
\hline
\end{tabular}

a Prezentowane dane są niepełne. W latach 1988-1991 odnoszą się tylko do kutrów w eksploatacji PPiUR „Koga” w Helu.

Źr ódło: Opracowanie własne na podstawie: Gospodarka rybna w latach 1971-1989. Materiały do badań, „Studia i Materiały MIR”, Seria E, Nr 38, 40, 43, 44, 45, 47, 48, 49, Gdynia 1978-1991; Gospodarka rybna w latach 1990-1996, „Studia i Materiały MIR”, Seria E, Nr 50, 52, 53, 56, 57, Gdynia 1994-1998.

Jednym z ważnych elementów tworzących polskie, państwowe rybołówstwo na Morzu Bałtyckim były stalowe burtowce typu B-25s, które jako efekt pierwszej fali modernizacyjnej zasiliły wszystkie państwowe kombinaty połowowe ${ }^{65}$. Ich późna kasacja, która z jednym wyjątkiem (PPiUR „Barka”) przypadała dopiero na koniec lat osiemdziesiątych XX w. ${ }^{66}$ Potwierdzeniem wysokiej efektywności były uśrednione wyniki połowowe na poziomie 700800 ton w skali roku. Dopiero po 1985 r. uwidocznił się spadek efektywności opisywanych kutrów, gdzie do decydujących czynników mających wpływ na

${ }^{65}$ Wprowadzenie do służby kutrów typu B-25s było jednym z najistotniejszych wydarzeń dla polskiej państwowej floty rybackiej na Morzu Bałtyckim. Jednostki te powiększyły potencjał floty. Wchodziły one do służby, kiedy istniało jeszcze PPiUR „Arka” w Gdyni, które otrzymało: Gdy-228, Gdy-229, Gdy-230 (1958 r.), Gdy-226, Gdy-283 (1959 r.), Gdy-169 (1960 r.), Gdy-170, Gdt-174, Gdy-175, Gdy-176 (1961 r.). W okresie późniejszym jednostki te rozdzielono między PPiUR „Koga” - powołane do życia 1 IV 1959 r. oraz PPiUR „Szkuner” - powołane do życia 1 I 1955 r. PPiUR „Koga” otrzymało: Hel-104, Hel-105 (1960 r.), Hel-106 (1962 r.), Hel-108 (1963 r.), Hel-109 (1964 r.), Hel-110, Hel-111 (1965 r.). PPiUR „Szkuner” otrzymało: Wła-106 (1958 r.), Wła-107, Wła-108, Wła-109, Wła-110, Wła-132, Wła-133 (1959 r.), Wła-136, Wła-137, Wła-138 (1960 r.), Wła-104, Wła-105 (1961 r.), Wła-139, Wła146, Wła-147, Wła-148, Wła-149 (1962 r.), Wła-150, Wła-151, Wła-152 (1963 r.), Wła-153 (1964 r.), Wła-154 (1965 r.). PPiUR „Korab” otrzymało: Ust-100, Ust-101 (1960 r.), Ust-103 (1963 r.), Ust-104, Ust-105 (1964 r.), Ust-106, Ust-107 (1965 r.), Ust-108 (1966 r.), Ust-99, Ust-109 (1967 r.). PPiUR „Kuter” otrzymało: Dar-150 (1963 r.), Dar-151 (1964 r.), Dar-152 (1966 r.), Dar-155, Dar-156 (1968 r.). PPiUR „Barka” otrzymało: Koł-155 (1963 r.), Koł-156, Koł-157 (1964 r.), Koł-158 91965 r.), Koł-160, Koł-161 (1966 r.). SPRM „Jedność Rybacka” otrzymała: Gda-15 (1968 r.). W ramach serii B-25s/B PPiUR „Koga” otrzymało Hel-136 (1971 r.), SPRM „Jedność Rybacka” otrzymała Gda-18, Gda-19 (1971 r.) (W. Blady, Polska flota rybacka..., s. 63, 66).

${ }^{66}$ PPiUR „Barka” wycofała kutry typu B-25s ze swojej floty w 1983 r. (Gospodarka rybna w latach 1983-1985..., s. 103). 
przebieg zjawiska należy włączyć wysłużenie oraz drastyczne zmniejszenie wydajności połowowej stad dorsza, głównego gatunku pozyskiwanego przez typ B-25s. Ostatnim analizowanym w tabeli 5, typem jednostki były burtowce typu B-25s/A. Należąc do drugiej fali modernizacyjnej polskiej floty kutrowej na Morzu Bałtyckim, przyczyniły się do wzrostu połowów i efektywności. Wprowadzane do służby od 1972 r. zasiliły floty wszystkich państwowych kombinatów, a w szczytowym momencie przypadającym na $1976 \mathrm{r}$. uzyskiwały średnio niemal 800 ton surowca w przeliczeniu na jednostkę.

\section{Tabela 6}

Uśrednione wyniki połowowe uzyskiwane przez kutry rufowe na Morzu Bałtyckim będące w eksploatacji PPiUR w latach 1971-1994 [t]

\begin{tabular}{|c|c|c|c|c|}
\hline \multirow{2}{*}{ Rok } & \multicolumn{4}{|c|}{ Typ kutra rufowego } \\
\hline & TR-27 & B-41 & B-403 & B-280 \\
\hline 1971 & 285,00 & - & - & - \\
\hline 1972 & 248,00 & - & - & - \\
\hline 1973 & 700,00 & - & - & - \\
\hline 1974 & 705,00 & - & - & - \\
\hline 1975 & 437,00 & - & - & - \\
\hline 1976 & 453,00 & 258,63 & - & - \\
\hline 1977 & 312,00 & 621,53 & - & - \\
\hline 1978 & 554,00 & 635,77 & 234,20 & - \\
\hline 1979 & 552,00 & 868,65 & 651,36 & - \\
\hline 1980 & 388,00 & 912,34 & 984,93 & - \\
\hline 1981 & 552,00 & 929,04 & 908,14 & - \\
\hline 1982 & 627,00 & 909,58 & 805,50 & - \\
\hline 1983 & 482,00 & 777,82 & 754,29 & - \\
\hline 1984 & 567,00 & 901,58 & 958,07 & - \\
\hline 1985 & 997,00 & 990,53 & 1034,86 & - \\
\hline 1986 & 747,00 & 893,62 & 1043,00 & - \\
\hline
\end{tabular}




\begin{tabular}{|c|c|c|c|c|}
\hline \multirow{2}{*}{ Rok } & \multicolumn{4}{|c|}{ Typ kutra rufowego } \\
\cline { 2 - 5 } & TR-27 & B-41 & B-403 & B-280 \\
\hline 1987 & 578,00 & 907,32 & 796,92 & - \\
\hline $1988^{\mathrm{a}}$ & 215,00 & 690,67 & $\cdot$ & 268,50 \\
\hline 1989 & 0,00 & 580,00 & $\cdot$ & 758,33 \\
\hline 1990 & 392,00 & 516,67 & $\cdot$ & 407,33 \\
\hline 1991 & 225,00 & 850,67 & $\cdot$ & 767,40 \\
\hline 1992 & 122,00 & 510,21 & 708,50 & 1160,79 \\
\hline 1993 & - & 202,60 & 130,67 & 711,11 \\
\hline 1994 & - & - & 11,00 & 2675,00 \\
\hline
\end{tabular}

a Prezentowane dane są niepełne. W latach 1988-1991 odnoszą się tylko do kutrów w eksploatacji PPiUR „Koga” w Helu.

Źr ódło: Opracowanie własne na podstawie: Gospodarka rybna w latach 1971-1989. Materiały do badań, „Studia i Materiały MIR”, Seria E, Nr 38, 40, 43-45, 47-49, Gdynia 1978-1991; Gospodarka rybna w latach 1990-1996, „Studia i Materiały MIR”, Seria E, Nr 50, 52, 53, 56, 57, Gdynia 1994-1998.

Drugą kategorią jednostek analizowaną na łamach niniejszego artykułu są kutry rufowe. Ich początki w państwowej flocie były bardzo skromne ponieważ w latach 1971-1974 eksploatowano ze słabymi efektami pojedynczy, eksperymentalny trawler typu TR-27, który nie rokował szans ewolucji tej klasy jednostek. Wraz z rozwojem polskiego przemysłu stoczniowego opracowano nowy projekt kutra rufowego typu B-410. Zasilił on floty wszystkich kombinatów połowowych i okazał się konstrukcją mającą duży wpływ na efektywność polskiego rybołówstwa. Potwierdzeniem były uśrednione wyniki połowowe, które wielokrotnie oscylowały w granicach 800-900 ton w skali roku. Należy wskazać, że większość jednostek omawianego typu znajdowała się w eksploatacji do 1993 r., a więc końca procesu prywatyzacji flot należących do państwowych przedsiębiorstw ${ }^{67}$.

Ewolucja konstrukcji trawlerów rufowych przyczyniła się do opracowania eksportowej wersji jednostki. Otrzymała ona oznaczenie B-403 i była przygotowywana głównie dla rybołówstwa NRD, aczkolwiek ostatecznie nie zasiliła flot planowanych odbiorców i wybudowane kutry, jak wskazano

${ }^{67}$ Aktualnie pojedynczy trawler typu B-410 znajduje się w eksploatacji „Szkuner” Sp. z o.o. i nosi oznaczenie Wła-305 (R. Białkowski, H. Gawlas, H. Spigarski, „Szkuner”..., s. 52). 
wcześniej, zostały przekazane głównie do PPiUR „Szkuner” oraz w mniejszym stopniu PPiUR „Barka”. Cechując się zbliżonymi właściwościami eksploatacyjnymi do poprzedniej konstrukcji osiągały podobne wyniki, gdzie na uwagę zasługuje szczególnie okres przypadający na lata 1985-1986. Wtedy kutry B-403 uzyskały w skali roku średnio ponad 1000 ton na jednostkę, co należało w przypadku rybołówstwa bałtyckiego uznać za wysoki wynik. Aktualnie w polskiej, państwowej flocie kutrowej na Morzu Bałtyckim znajduje się w eksploatacji pojedynczy kuter typu B-403 - Wła-295, którego armatorem jest „Szkuner” we Władysławowie ${ }^{68}$.

Ostatnią grupą jednostek, które zasiliły państwową flotę kutrową były trawlery typu B-280, efekt decyzji podjętych jeszcze w $1983 \mathrm{r}^{69}$ Istotnie jednostki określane jako piąta fala modernizacyjna zasiliły w latach 1988-1991 floty wszystkich kombinatów, aczkolwiek PPiUR „Barka” nie brała udziału w implementacji tego projektu skupiając swoje wysiłki na kutrach typu TMC- $001^{70}$. W warunkach drastycznie obniżającej się wydajności biologicznej przy jednoczesnym spadku produktywności ich wpływ na państwową flotę kutrową był niewielki. Pewnym było, że znajdowały się w eksploatacji do końca procesu transformacji struktury własności we flocie z wyjątkiem wykorzystywania ich przez PPiUR „Szkuner” do czasów dzisiejszych ${ }^{71}$.

\section{Analiza wydajności polskiej państwowej floty kutrowej na Morzu Bałtyckim w latach 1971-2001}

Ostatnim elementem prowadzonej analizy jest próba wskazania wydajności państwowej floty kutrowej na Morzu Bałtyckim. W tym celu wzięto pod uwagę czynniki związane z technicznym uzbrojeniem floty wyrażonym w KM (moc silników) oraz wyporność floty kutrowej w GT. Drugim elementem jest wydajność $w$ przeliczeniu na pojedynczego zatrudnionego oraz rybaka w tonach na osobę.

W przypadku danych zamieszczonych na rysunku 8 pierwszym elementem analizy są połowy uzyskane przez flotę w przeliczeniu na moc wyrażoną w KM. Za moment szczytowy należy uznać rok 1975, kiedy współczynnik wynosił 2,76 t/KM, co było powiązane $\mathrm{z}$ drugą falą modernizacyjną floty (jednostki typu B-25s/A o mocy nominalnej siłowni głównej wynoszącej

${ }^{68}$ Ibidem, s. 44.

${ }^{69}$ J. Lisiecki, Założenia współczesnej polityki morskiej PRL i jej realizacja, [w:] Polityka morska państwa w 40-leciu PRL, Gdańsk 1986, s. 24.

70 Do służby w PPiUR „Barka” wcielono w 1991 r. dwa kutry typu B-280 i otrzymały one oznaczenia Koł-6 oraz Koł-7 (W. Blady, Polska flota rybacka..., s. 83).

${ }^{71}$ PPiUR „Szkuner” we Władysławowie posiada we flocie trzy jednostki typu B-280 - Wła310, Wła-311 oraz Wła-312. 


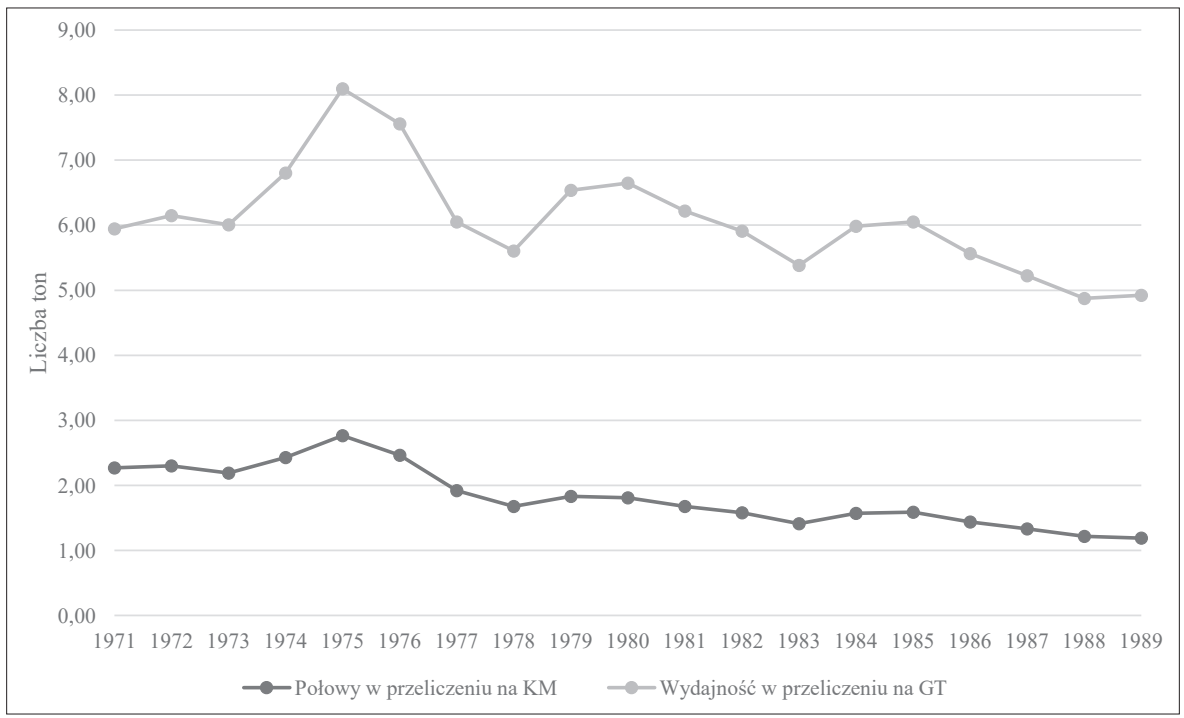

Rys. 8. Połowy polskiej, państwowej floty kutrowej w przeliczeniu na KM oraz GT w latach 1971-1989 [t]

Źr ódło: Opracowanie własne na podstawie: Gospodarka rybna w latach 1971-1989. Materiały do badań, „Studia i Materiały MIR”, Seria E, Nr 38, 40, 43-45, 47-49, Gdynia 1978-1991.

$350 \mathrm{KM}$ ) oraz najwyższym poziomem uzyskania surowca w całym badanym okresie. Należy zwrócić uwagę na fakt niskiej mocy silników, w które były wyposażone jednostki wcześniejszych typów, gdzie średnia moc oscylowała w granicach $210-247 \mathrm{KM}^{72}$. W późniejszym okresie wraz ze wzrostem nominalnej mocy siłowni głównych (jednostki typu B-410 oraz B-403 o mocy $570 \mathrm{KM}$ ) badana wartość obniżyła się. Dodatkowo dał o sobie znać stopniowy spadek efektywności z wyłączeniem lat 1979, 1980 i 1981, kiedy łączny wolumen połowów wzrósł. Najniższa wydajność w przeliczeniu na KM przypadała zgodnie z wcześniejszymi ustaleniami na 1983 r., kiedy wyraźnie obniżyło się uzyskanie surowca na Morzu Bałtyckim.

Drugim elementem analizowanym na rysunku 8 jest wydajność połowowa w przeliczeniu na GT. Określa ona ile ton surowca przypadało średnio na 1 GT wyporności państwowej floty kutrowej. Przez pierwsze trzy lata pozostała na niemal niezmiennym poziomie, co było powiązane ze względną stałością liczby jednostek oraz ustabilizowanymi połowami. Okres późniejszy związany z wprowadzaniem do służby nowych jednostek przyczynił się

72 Zgodnie $\mathrm{z}$ informacjami zawartymi w literaturze przedmiotu jednostki typów B-12, B-25 oraz B-25s były wyposażone głównie w silniki o mocy maksymalnej 225 KM (W. Blady, Polska flota rybacka..., s. 60, 62, 66). 
do wzrostu łącznej wyporności, która osiągnęła wartość około 20 tys. GT. Dynamiczny rozwój floty objawił się poprawą wydajności, która w szczytowym momencie w $1975 \mathrm{r}$. wynosiła 8,10 t/GT ${ }^{73}$. W późniejszym okresie wraz ze spadkiem połowów uwidocznił się wzrost wyporności floty, co zaowocowało zmniejszeniem badanego wskaźnika. Za kolejny szczytowy moment należy uznać 1980 r., kiedy wielkość przekroczyła poziom 6,65 t/GT i wartość ta do 1989 r. nigdy nie została przekroczona. Dla całego okresu najniższy wynik uzyskano w 1983 r., kiedy na tonę GT przypadało 4,79 t surowca. Po tym okresie flota kutrowa wykazywała zmienne wyniki, co było powiązane z wycofywaniem ze służby poszczególnych grup jednostek oraz stałym ubytkiem połowów ${ }^{74}$.

Podjęta na rysunku 9 analiza analogicznych wskaźników w dobie transformacji wskazywała zupełnie inne wartości niż ta w ramach gospodarki centralnie planowanej. W 1990 r. wielkość połowów przypadająca na 1 KM mocy siłowni głównych kutrów osiągnęła najniższą wartość w całym badanym okresie - 1,04 t/KM. Było to spowodowane dalszym obniżeniem się wyników uzyskiwanych przez państwową flotę kutrową, która złowiła poniżej 80 tys. ton ryby. Tak niska wartość zbiegła się ze wzrostem mocy floty w ujęciu globalnym, co było wynikiem wprowadzania do służby jednostek typu B-280, wyposażonych w 570 konne siłownie główne. Zmiana struktury floty wraz z wprowadzeniem w życie postulatów prywatyzacyjnych spowodowała w teorii stopniowy wzrost wydajności, jednakże był on powiązany z redukcją połowów, które obniżyły się o ponad 20 tys. ton przy jednoczesnym ubytku mocy. Sytuacja ta miała zwłaszcza miejsce w latach 1991-199375. W późniejszym okresie tylko dwóch państwowych armatorów PPiUR „Szkuner” oraz SPRM „Bałtyk” prowadziło połowy. Znalazło to odzwierciedlenie $\mathrm{w}$ ponad dwukrotnym wzroście efektywności połowowej, która osiągnęła poziom 3,55 t/KM. W kolejnych latach wraz z zaprzestaniem eksploatacji floty przez SPRM „Bałtyk” i wejściem na bałtyckie łowiska spółki „Dalmor-Bałtyk” wskaźnik uległ widocznemu obniżeniu, oscylując w granicach poniżej 3 t/KM. Od 1998 r. eksploatacja łowisk na Morzu Bałtyckim realizowana była wyłącznie przez PPiUR „Szkuner” we Władysławowie, co pomimo początkowych spadków objawiało się znacznym wzro-

${ }^{73}$ Łączna wyporność państwowej floty kutrowej w 1975 r. 18248 GT, a osiągnięte połowy 148060 ton (Gospodarka rybna w latach 1975-1977..., s. 106, 131).

${ }^{74}$ Rozpoczęty pod koniec lat osiemdziesiątych XX w. proces oddawania w leasing lub ajencję wysłużonych kutrów spowodował ubytek wyporności rzędu niemal 2500 GT (różnica między stanem floty w 1984 r. oraz 1989 r.) (Gospodarka rybna w latach 1983-1985 ..., s. 103, 141; Gospodarka rybna w latach 1986-1989..., tab. 3, tab. 48).

${ }^{75}$ Gospodarka rybna w latach 1990-1992..., s. 27, 58. 


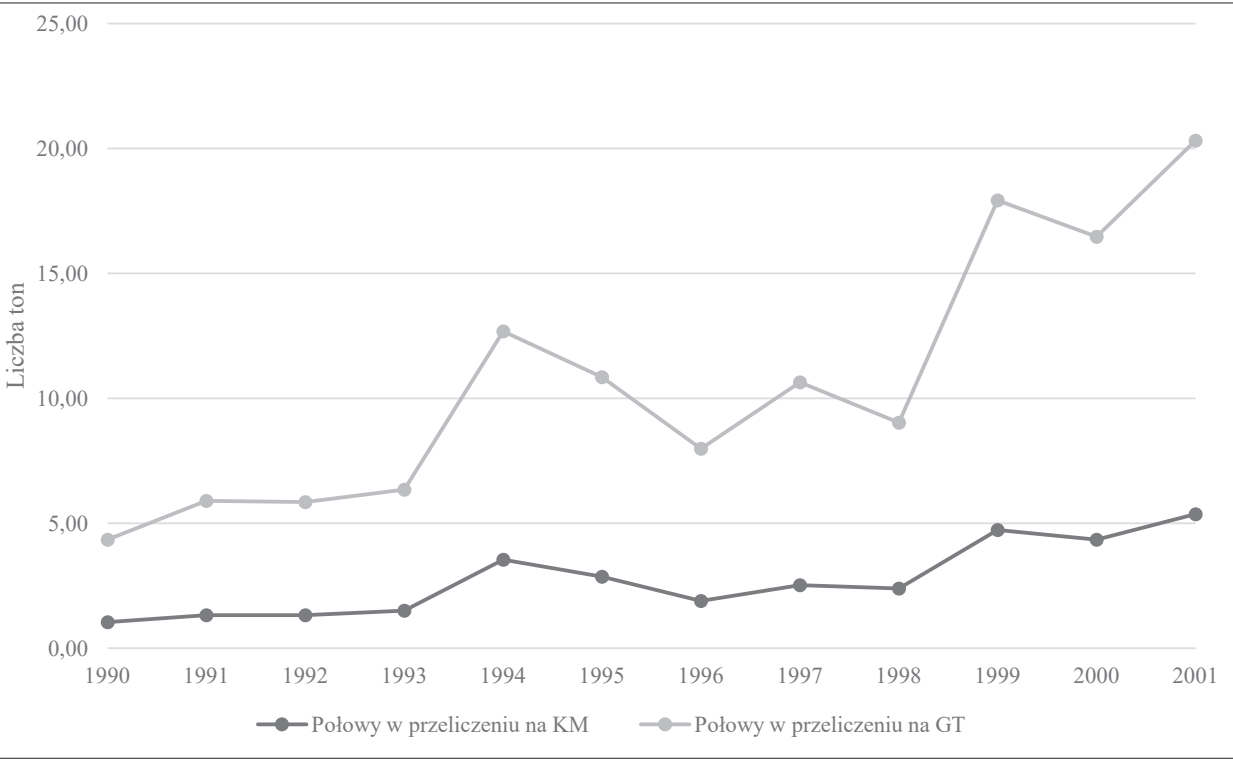

Rys. 9. Połowy polskiej, państwowej floty kutrowej w przeliczeniu na KM oraz GT w latach 1990-2001 [t]

Źródło: Opracowanie własne na podstawie: Gospodarka rybna w latach 1990-1996, „Studia i Materiały MIR", Seria E, Nr 50, 52, 53, 56, 57, Gdynia 1994-1998; Rybołówstwo polskie 1996-2002, „Studia i Materiały MIR”, Seria E, Nr 55, 58, 59, 61, 63, 64, 66, Gdynia 1998-2004.

stem efektywności, która do 2001 r. stale przekraczała początkowo poziom $4 \mathrm{t} / \mathrm{KM}$, a później $5 \mathrm{t} / \mathrm{KM}$, co należy uznać za wynik satysfakcjonujący ${ }^{76}$.

Analiza wydajności w przeliczeniu na wyporność wyrażoną w GT nasuwa analogiczne wnioski. W początkowej fazie badanego okresu wprowadzane do służby kutry typu B-280 w znaczącym stopniu wpłynęły na wzrost łącznej wyporności państwowej floty kutrowej, która zbliżyła się do pułapu 17 tys. GT. Przy jednoczesnym obniżeniu połowów spowodowało to nieznaczny regres wskaźnika wydajności do poziomu 4,35 t/GT. Lata późniejsze obok wyzbywania się jednostek przyniosły obniżenie się wolumenu połowów, jednakże pierwszy ze wskazanych elementów spadał w o wiele

${ }^{76}$ W momencie zakończenia procesów transformacji, przypadającego na lata 1998-2001, znacząco wzrosła efektywność państwowej floty kutrowej na Morzu Bałtyckim. W 1998 r. techniczne uzbrojenie pracy wyrażone w t/KM wynosiło 2,39, w 1999 r. - 4,74 t/KM, w $2000 \mathrm{r}$. - 4,35 t/KM, w 2001 r. - 5,37 t/KM. Należy wskazać, że ostatnia wartość była najwyższa dla całego badanego okresu, aczkolwiek wynikała ze wzrostu rocznych połowów „Szkunera” i zakończonego procesu prywatyzacji floty kutrowej. 
wyższym tempie, co przyczyniło się do znacznego wzrostu wydajności ${ }^{77}$. Pierwszym dużym skokiem średniej wydajności był rok 1994, kiedy przekroczyła ona poziom 12 t/GT, co było związane z ograniczeniami w eksploatacji flot do zaledwie dwóch armatorów („Szkuner” i „Bałtyk”). Lata następne przyniosły ponowne obniżenie wydajności, gdzie najsłabszy był $1996 \mathrm{r}^{78}$ Zakończenie procesu restrukturyzacji państwowej floty kutrowej spowodowało, że wskaźnik średniej wydajności w t/GT rozpoczął od $1998 \mathrm{r}$. uzyskiwać bardzo dobre wyniki z momentem szczytowym w 2001 r. $^{79}$

\section{Tabela 7}

Wydajność polskiej, państwowej floty kutrowej operującej na Morzu Bałtyckim w przeliczeniu na zatrudnionych w latach 1971-2001 [t/os]

\begin{tabular}{|c|c|c|c|c|}
\hline \multirow{2}{*}{ Rok } & \multicolumn{2}{|c|}{ Połowy PPiUR } & \multicolumn{2}{c|}{ Połowy SPRM } \\
\cline { 2 - 5 } & $\begin{array}{c}\text { W przeliczeniu na } \\
\text { zatrudnionego }^{\text {a }}\end{array}$ & $\begin{array}{c}\text { W przeliczeniu } \\
\text { na rybaka }\end{array}$ & $\begin{array}{c}\text { W przeliczeniu } \\
\text { na zatrudnionego }\end{array}$ & $\begin{array}{c}\text { W przeliczeniu } \\
\text { na rybaka }\end{array}$ \\
\hline 1971 & 15,32 & 52,20 & 11,38 & 35,92 \\
\hline 1972 & 16,04 & 55,96 & 12,90 & 42,79 \\
\hline 1973 & 16,35 & 57,59 & 12,31 & 41,56 \\
\hline 1974 & 18,76 & 65,76 & 12,84 & 44,18 \\
\hline 1975 & 22,53 & 78,17 & 14,61 & 47,74 \\
\hline 1976 & 21,69 & 70,73 & 12,43 & 40,58 \\
\hline 1977 & 17,71 & 57,41 & 11,09 & 36,66 \\
\hline 1978 & 16,81 & 54,60 & 11,37 & 38,00 \\
\hline 1979 & 20,00 & 64,81 & 14,59 & 47,22 \\
\hline 1980 & 20,85 & 66,98 & 14,85 & 46,47 \\
\hline 1981 & 19,23 & 62,28 & 13,64 & 41,87 \\
\hline 1982 & 18,86 & 61,52 & 14,99 & 45,50 \\
\hline
\end{tabular}

77 W roku 1990 wyporność państwowej floty kutrowej wynosiła 16954 GT, a połowy przez nią uzyskane 73690 t. W roku następnym wyporność obniżyła się o niemal $6100 \mathrm{GT}$, a połowy spadły o około 10 tys. ton.

${ }^{78}$ Wtedy do eksploatacji łowisk bałtyckich włączono spółkę „Dalmor-Bałtyk” Sp. z o.o.

${ }^{79}$ W 2001 r. jednostki znajdujące się w eksploatacji PPiUR „Szkuner” osiągnęły średnią wydajność rzędu 20,32 t/GT (Rybołówstwo polskie 2001..., s. 9, 26). 


\begin{tabular}{|c|c|c|c|c|}
\hline \multirow{2}{*}{ Rok } & \multicolumn{2}{|c|}{ Połowy PPiUR } & \multicolumn{2}{|c|}{ Połowy SPRM } \\
\hline & $\begin{array}{c}\text { W przeliczeniu na } \\
\text { zatrudnionego }^{\mathrm{a}}\end{array}$ & $\begin{array}{c}\text { W przeliczeniu } \\
\text { na rybaka }^{\mathrm{b}}\end{array}$ & $\begin{array}{c}\text { W przeliczeniu } \\
\text { na zatrudnionego }\end{array}$ & $\begin{array}{c}\text { W przeliczeniu } \\
\text { na rybaka }\end{array}$ \\
\hline 1983 & 17,14 & 58,97 & 12,59 & 40,17 \\
\hline 1984 & 19,14 & 68,82 & 13,43 & 44,16 \\
\hline 1985 & 19,34 & 72,48 & 11,23 & 38,23 \\
\hline 1986 & 17,21 & 67,60 & 10,02 & 35,51 \\
\hline 1987 & 16,08 & 63,15 & 8,60 & 32,82 \\
\hline 1988 & 14,80 & 58,20 & 7,57 & 28,35 \\
\hline 1989 & 15,02 & 59,24 & 7,12 & 25,93 \\
\hline 1990 & 15,07 & 58,12 & 6,34 & 23,58 \\
\hline 1991 & 14,92 & 60,62 & 5,24 & 20,83 \\
\hline 1992 & 12,56 & 70,93 & . & . \\
\hline 1993 & 4,97 & 45,49 & . & . \\
\hline 1994 & 3,72 & 109,36 & . & . \\
\hline 1995 & 4,14 & 233,51 & . & . \\
\hline 1996 & 5,24 & 232,67 & . & . \\
\hline 1997 & . & 232,69 & . & . \\
\hline 1998 & . & 133,33 & . & . \\
\hline 1999 & 15,96 & 259,62 & . & . \\
\hline 2000 & 18,32 & 243,14 & . & . \\
\hline 2001 & 23,61 & 306,00 & . & . \\
\hline
\end{tabular}

a W przypadku PPiUR oraz SPRM była to całość zatrudnionych w przedsiębiorstwie.

b W przypadku PPiUR chodzi o wyłącznie o rybaków, którzy w strukturach państwowych przedsiębiorstw wchodzili w skład wydziałów połowów.

Źr ódło: Opracowanie własne na podstawie: Gospodarka rybna w latach 1971-1996. Materiały do badań, „Studia i Materiały MIR”, Seria E, Nr 38, 40, 43-45, 47-50, 52, 53, 56, 57, Gdynia 1978-1998; Rybołówstwo polskie 1996-2002, „Studia i Materiały MIR”, Seria E, Nr 55, 58, 59, 61, 63, 64, 66, Gdynia 1998-2004. 
Zaprezentowane w tabeli 7 dane omawiają zagadnienie średniej wydajności $\mathrm{w}$ przeliczeniu na ogół zatrudnienia oraz pracowników wydziału połowów państwowych podmiotów eksploatujących kutry na łowiskach Morza Bałtyckiego ${ }^{80}$. W przypadku pierwszej $\mathrm{z}$ analizowanych wartości opisującej wyniki połowowe przypadające na pojedynczego zatrudnionego należy przyjąć dwa obostrzenia badawcze. Pierwszym z nich jest zmienna wielkość połowów w czasie oraz zmienność poziomu zatrudnienia, które wzrastało do 1980 r., a od tego momentu początkowo nieznacznie spadało, aby w okresie transformacji cechować się znacznym ubytkiem wartości. Szczytowe momenty uśrednionej wydajności pokrywały się najwyższymi wynikami połowowymi całej floty kutrowej, które przypadały na 1975 r. oraz lata 1979-1982. W latach transformacji produktywność państwowego rybołówstwa w przeliczeniu na wszystkich zatrudnionych od 1992 r. spadała, co było powiązane z procesem racjonalizacji zatrudnienia oraz prowadzonej prywatyzacji floty kutrowej ${ }^{81}$. Dane z lat 1997-1998 nie zachowały się. W momencie zakończenia przekształceń, gdy jedynym przedsiębiorstwem państwowym eksploatującym flotę kutrową pozostał PPiUR „Szkuner” wydajność rozpoczęła wzrastać, osiągając w 2001 r. najwyższą wartośćci2.

Drugim zagadnieniem omówionym w tabeli 7 jest wydajność przypadająca na pojedynczego rybaka. Najwyższe wyniki osiągnięto w latach 19791982 oraz 1985-1987. Oba przypadki wpasowywały się w ogólne trendy państwowego rybołówstwa. Anomalię stanowią natomiast lata 1984-1986, kiedy wraz ze spadkiem zatrudnienia i chwilowym wzrostem globalnej ilości uzyskanego surowca wyczuwalny był wzrost średniej wydajności, która ponownie oscylowała w granicach 68-72 t/rybaka. Koniec lat osiemdziesiątych i początek dziewięćdziesiątych XX w., cechował się wydajnością oscylu-

${ }^{80}$ W skład ogółu zatrudnionych należy włączyć pracowników lądowych zarówno produkcyjnych, jak i tworzących kadrę zarządzającą oraz pracującą w działach pomocniczych (maszynownie, fabryki lodu, magazyny i myjnie opakowań, działy kontroli jakości itp.).

${ }^{81}$ Zgodnie z informacjami zawartymi w niepublikowanym opracowaniu Emila Kuzebskiego od 1990 r. w przedsiębiorstwach państwowych dokonano znaczącej redukcji zatrudnienia. W PPiUR „Koga” z 575 pracowników w 1990 r. do 1994 r. utrzymano 161 etatów. W PPiUR „Szkuner” spośród 1435 pracowników w 1990 r. pozostało 631 osób. W PPiUR „Korab” w 1990 r. zatrudniano 915 osób, a w 1994 r. pozostało 437 pracowników. W PPiUR „Kuter” z 880 osób w 1990 r. pozostało 414 osób. W PPiUR „Barka” spośród 1085 osób zatrudnionych w 1990 r., do 1994 zatrudnienie zredukowano do 534 osób (AEK MIR, E. Kuzebski, Analiza przekształceń własnościowych i strukturalnych $w$ państwowych przedsiębiorstwach połowowych, Gdynia 1995, [maszynopis niepublikowany], s. 64).

${ }^{82}$ Działania były związane z ograniczaniem zatrudnienia w „Szkunerze” oraz dużym wzrostem połowów wykazanym przez przedsiębiorstwo (R. Białkowski, H. Gawlas, H. Spigarski, „Szkuner"..., s. 79). 
jącą w granicach 58-60 t/rybaka, co należało uznać za wynik nieodbiegający od ogólnej tendencji83. Widoczny spadek wydajności przypadł na 1993 r., kiedy oba wskaźniki zmniejszyły się, aczkolwiek nie był on proporcjonalny ${ }^{84}$. Wskazany wcześniej rok 1993 należy uznać za końcowy okres wyzbywania się przez przedsiębiorstwa flot, a w związku z tym ograniczeniem działalności połowowej. Pod koniec transformacji najlepsze wyniki przypadały na lata 1995-1997, kiedy państwowe jednostki uzyskiwały średnio powyżej 230 t/rybaka. Zakończenie zmian w strukturze floty kutrowej na Bałtyku w 2001 r. przyniosło wartość rekordową, która wynosiła 306 t/rybaka z zastrzeżeniem utrzymania zatrudnienia tej grupy osób w PPiUR „Szkuner" na poziomie około 50 osób.

Analizując SPRM eksploatujące kutry na Morzu Bałtyckim pierwszy wniosek dotyczy o wiele mniejszej wydajności w przeliczeniu na ogół zatrudnienia $\mathrm{w}$ prezentowanych podmiotach. Oscylował on głównie w granicach 11 t/zatrudnionego, w kilku szczytowych momentach przekraczając poziom 14 ton. Co istotniejsze uwidocznił się spadek omawianej wartości, która od poziomu ponad 11 ton w $1991 \mathrm{r}$. spadła do średnio 5 t/zatrudnionego. SPRM nieustanie do 1982 r. zmniejszały liczbę etatów, co było zgodne z panującymi ówcześnie $\mathrm{w}$ gospodarce rybnej tendencjami ${ }^{85}$. W połączeniu $\mathrm{z}$ obniżającą się wydajnością przyczyniło się to do zmniejszenia uśrednionych wyników połowowych w przeliczeniu na zatrudnionego. Przeprowadzona kwerenda wskazała brak danych za lata 1992-2001, co uniemożliwiło dalszą analizę.

Ostatnim czynnikiem prezentowanym w tabeli 7, jest uśredniona wydajność połowowa przypadająca na pojedynczego rybaka w SPRM. Można wskazać, że w badanym okresie do 1986 r. oscylowała ona w przedziale 35-47 t/rybaka. W przypadku SPRM momenty szczytowe przypadały na zupełnie inne lata niż w PPiUR. Najwyższy poziom wskaźnik osiągnął w latach 1972-1974, 1979-1980 oraz w 1982 i 1984 r. W pełni pokrywają się lata spadkowe przypadające na 1978 i 1983 r., co potwierdza tendencje panujące w całej gospodarce rybnej. Wraz z procesem prywatyzacji spółdzielni, pomimo spadku zatrudnienia, wskaźnik ulegał stałemu obniżeniu. Nie istnieje możliwość zbadania, go po $1992 \mathrm{r}$.

83 Osiągnięte w latach 1988-1992 uśrednione wyniki połowowe były związane ze stopniowym ograniczeniem zatrudnienia.

${ }^{84}$ W 1993 r. liczba zatrudnionych zmniejszyła się ponad o połowę (z 616 osób w 1992 r. do 297 osób w 1993 r.), a połowy spadły trzykrotnie (z 43693 ton w 1992 r. do 13512 ton w 1993 r.).

${ }^{85}$ Przykładowo w 1981 r. SPRM eksploatujące kutry zatrudniały 2716 osób. W 1985 r. 2529 osób, a w 1989 r. 2004 osoby (Gospodarka rybna w latach 1983-1985..., s. 308; Gospodarka rybna w latach 1986-1989..., tab. 112). 


\section{Podsumowanie}

Na przestrzeni lat 1971-2001 w polskiej, państwowej flocie kutrowej zaszły daleko posunięte zmiany. Obok pięciu fal modernizacji jednostek pływających uwidoczniły się tendencje do obniżenia wydajności pracy oraz łącznych połowów, które w 1989 r. osiągnęły najniższy od niemal 20 lat poziom. Przyjęta odgórnie zasada centralnego planowania w rybołówstwie przyczyniła się do zmniejszenia elastyczności, co miało zły wpływ na późniejszą restrukturyzację i prywatyzację państwowych kombinatów oraz spółdzielni. Rozpoczęty w 1990 r. proces zmian strukturalnych przyczynił się do marginalizacji pozycji rynkowej poszczególnych podmiotów, a osiągane wyniki ekonomiczne były dalekie od planów. Niesprzyjające okazały się przyjęte wytyczne prywatyzacyjne, gdzie do najważniejszych błędów należy zaliczyć wyzbycie się floty kutrowej oraz rozdzielenie majątku produkcyjnego, co nie miało miejsca tylko w przypadku PPiUR „Szkuner”. Dały o sobie znać również problemy finansowe w efekcie, których dokonywano wyprzedaży części majątku oraz niedostosowanie struktury wewnętrznej i mechanizmów działania kombinatów do nowych zasad funkcjonowania gospodarki. Ostatecznie proces prywatyzacyjny zakończono w 2001 r., kiedy większość likwidowanych podmiotów będących elementami analizy ogłosiła upadłość. Wytworzona od 1991 r. sytuacja miała również dobre strony, gdzie do najważniejszych należało zaliczyć zmianę struktury własności z dominującą rolą podmiotów prywatnych. Pozwoliło to na uwolnienie rynku, którego domeną stał się niemal nieograniczony dostęp do surowca. Podsumowując, na przestrzeni badanych trzydziestu lat doszło do całkowitej transformacji państwowego rybołówstwa kutrowego, gdzie do najważniejszych aspektów należało zaliczyć gruntowną zmianę struktury floty, a finalnie zupełnie odmienny podział własności z dominacją indywidualnej. Z perspektywy czasu zmiany te należy uznać za korzystne, ponieważ przyczyniły się do rozwoju rybołówstwa oraz regionów związanych z branżą.

\section{BIBLIOGRAFIA}

\section{Żródła archiwalne}

Analiza ekonomiczna rybołówstwa morskiego za 1995 rok, red. S. Szostak, G. Aguirre, J. Grzenia i inni, Gdynia 1996 [maszynopis niepublikowany].

Archiwum Firmowe Przedsiębiorstwa Połowów i Usług Rybackich „Koga” w Helu. Archiwum Zakładu Ekonomiki Rybackiej Morskiego Instytutu Rybackiego. 
Biuletyn jubileuszowy 1989, Hel 1989.

Kuzebski E., Analiza przekształceń własnościowych i strukturalnych w państwowych przedsiębiorstwach połowowych, Gdynia 1995, [maszynopis niepublikowany].

Kuzebski E., Ocena efektów ekonomicznych zmian strukturalnych i własnościowych w państwowych przedsiębiorstwach połowowych, Gdynia 1996 [maszynopis niepublikowany].

Modernizacja przetwórstwa rybnego z połowów bałtyckich, red. Z. Polański, A. Brzyski, P. Bykowski i inni, Gdynia 1991 [maszynopis niepublikowany].

Morska gospodarka rybna PRL 1945-1985, red. W. Borowski, P. Bykowski, D. Dutkiewicz i inni, Gdynia 1989.

Polański Z., Russek Z., Propozycje i warunki przekształceń własnościowych w polskiej gospodarce rybnej /projekt wstępny/, Gdynia 1990 [maszynopis niepublikowany].

Polański Z., Szostak S., Analiza ekonomiczna rybołówstwa morskiego za 1990 rok, Gdynia 1991.

Polański Z., Sytuacja polskiego rybołówstwa na Bałtyku. Nakład połowowy, połowy, efekty, limity, Gdynia 1991 [maszynopis niepublikowany].

Sprzedaż Hel 153 Hel 154, Agreement between Cadilu Fishing PTY Ltd. and crew of the Hel 154.

Sprzedaż Hel 153 Hel 154, Fax z 13.03.1993 r.

Sprzedaż Hel 153 Hel 154, Memorandum of agreement.

Szostak S., Russek Z., Analiza ekonomiczno-finansowa Przedsiębiorstwa Połowów i Usług Rybackich „Koga” w Helu za lata 1988-1990 i pierwsze półrocze 1991 r. [brak daty i miejsca wydania, maszynopis niepublikowany].

\section{Źródła wywołane}

Rozmowa z armatorem kutra Hel-152 Edwardem Koreńczukiem [w kolekcji autora].

\section{Opracowania}

Białkowski R., Gawlas H., Spigarski H., „Szkuner” Port - Szkuner - Miasto, Gdańsk 2005.

Blady W., Polska flota rybacka w latach 1921-2001. Kalendarium tragicznych zdarzeń na statkach rybackich w latach 1945-2001, Gdynia 2002.

Duda D., Wandtke B., Port Hel. Przyczynek do 100-letniej historii, Gdynia 1993.

Gospodarka rybna w latach 1971-1973. Materiały do badań, „Studia i Materiały MIR”, Seria E, nr 29, red. R. Maj, K. Siudziński, J. Popiel i inni, Gdynia 1975.

Gospodarka rybna w latach 1972-1974. Materiały do badań, „Studia i Materiały MIR”, Seria E, nr 31, red. R. Maj, K. Siudziński, J. Popiel i inni, Gdynia 1976.

Gospodarka rybna w latach 1973-1975. Materiały do badań, „Studia i Materiały MIR, Seria E, nr 35, red. R. Maj, D. Dutkiewicz, H. Ganowiak i inni, Gdynia 1978.

Gospodarka rybna w latach 1974-1976. Materiały do badań, „Studia i Materiały MIR”, Seria E, nr 40, red. R. Maj, P. Bykowski, D. Dutkiewicz i inni, Gdynia 1979.

Gospodarka rybna w latach 1975-1977. Materiały do badań, „Studia i Materiały MIR”, Seria E, nr 43, red. B. Draganik, P. Bykowski, D. Dutkiewicz i inni, Gdynia 1979.

Gospodarka rybna w latach 1976-1978. Materiały do badań, „Studia i Materiały MIR”, Seria E, nr 44, red. B. Draganik, P. Bykowski, D. Dutkiewicz i inni, Gdynia 1982. 
Gospodarka rybna w latach 1977-1979. Materiały do badań, „Studia i Materiały MIR”, Seria E, nr 45, brak redakcji, Gdynia 1984.

Gospodarka rybna w latach 1979-1981. Materiały do badań, „Studia i Materiały MIR”, Seria E, nr 47, red. P. Bykowski, H. Ganowiak, J. Krępa i inni, Gdynia 1986.

Gospodarka rybna w latach 1981-1983. Materiały do badań, „Studia i Materiały MIR”, Seria E, nr 48, red. P. Bykowski, H. Ganowiak, J. Krępa i inni, Gdynia 1986.

Gospodarka rybna w latach 1983-1985. Materiały do badań, „Studia i Materiały MIR”, Seria E, nr 49, red. W. Borowski, P. Bykowski, H. Ganowiak i inni, Gdynia 1990.

Gospodarka rybna w latach 1986-1989, red. J. Grzenia, M. Gustowska, T. Jasińska i inni, Gdynia 1991.

Gospodarka rybna w latach 1990-1992, „Studia i Materiały MIR”, Seria E, red. J. Grzenia, M. Gustowska, E. Makowiecka i inni, Gdynia 1994.

Gospodarka rybna w latach 1991-1993, „Studia i Materiały MIR”, Seria E, nr 52, red. J. Grzenia, M. Gustowska, E. Makowiecka i inni, Gdynia 1995.

Gospodarka rybna w latach 1992-1994, „Studia i Materiały MIR”, Seria E, nr 53, red. J. Grzenia, M. Gustowska, E. Kuzebski, Gdynia 1996.

Gospodarka rybna w latach 1994-1996, „Studia i Materiały MIR”, Seria E, nr 57, red. J. Grzenia, E. Makowiecka, H. Wołoszyk, Gdynia 1998.

Kołodziej K., Przedsiębiorstwa przetwórstwa rybnego w Polsce, „Wiadomości Rybackie”, 1994, nr 5.

Kubicki M., Modernizacja floty PPiUR „Koga” w Helu. Wprowadzenie do służby trawlerów rufowych typu B-410 w latach 1974-1980, „Zapiski Puckie”, 2016, nr 15.

Kubicki M., Modernizacja floty rybackiej Przedsiębiorstwa Połowów i Usług Rybackich „Koga” w Helu - budowa i wprowadzenie do służby kutrów rybackich typu B-280 w latach 19861991, [w:] Additamenta Historica. Studia z dziejów dalekich i bliskich, red. B. Klassa, Gdańsk 2016.

Kuciewicz P., O śledziu i prywatyzacji, „Wiadomości Rybackie”, 1993, nr 2.

Kuciewicz P., Przełomowy rok „Korabia”, „Wiadomości Rybackie”, 1996, nr 7.

Kuciewicz P., Tonaca „Barka”, „Wiadomości Rybackie”, 1996, nr 6.

Leszczyński R., Tragedie rybackiego morza, t. 1, Gdynia-Gdańsk 2005.

Lisiecki J., Założenia współczesnej polityki morskiej PRL i jej realizacja, [w:] Polityka morska państwa w 40-leciu PRL, Gdańsk 1986.

Loos M., Prywatyzacja darłowskiego „Kutra”, „Wiadomości Rybackie”, 1995, nr 6.

Rybołówstwo polskie 1996, „Studia i Materiały MIR”, Seria E, nr 55, red. S. Szostak, E. Kuzebski, B. Pieńkowska i inni, Gdynia 1998.

Rybołówstwo polskie 1997, „Studia i Materiały MIR”, Seria E, nr 58, red. S. Szostak, E. Kuzebski, B. Pieńkowska i inni, Gdynia 1999.

Rybołówstwo polskie 1998, „Studia i Materiały MIR”, Seria E, nr 59, red. S. Szostak, E. Kuzebski, B. Pieńkowska i inni, Gdynia 2000.

Rybołówstwo polskie 1999, „Studia i Materiały MIR”, Seria E, nr 61, red. S. Szostak, E. Kuzebski, B. Pieńkowska i inni, Gdynia 2001.

Rybołówstwo polskie 2000, „Studia i Materiały MIR”, Seria E, nr 63, red. S. Szostak, E. Kuzebski, B. Pieńkowska i inni, Gdynia 2002. 
Rybołówstwo polskie 2001, „Studia i Materiały MIR”, Seria E, nr 64, red. S. Szostak, E. Kuzebski, B. Pieńkowska, Gdynia 2003.

Rynek ryb stan i perspektywy, 2004, nr 1, red. J. Seremak-Bulge, S. Szostak, E. Kuzebski i inni, Warszawa 2005.

Spigarski H., Stocznia remontowa Nauta S.A. Dla marzeń i wyzwań, Gdańsk 2006.

Szostak S., Polskie rybołówstwo w latach 1990-1995, „Studia i Materiały Morskiego Instytutu Rybackiego", Seria E, nr 54, Gdynia 1996.

Ustawa z dnia 13 lipca 1990 r. o prywatyzacji przedsiębiorstw państwowych (Dz.U. Nr 51, poz. 298).

Zieziula J., Polska gospodarka rybna w okresie transformacji (1990-2001). Teoria i praktyka, Gdynia 2002.

http://www.krs-online.com.pl, dostęp: 27.08.2018.

Mateusz Kubicki

\section{AN ANALYSIS AND EVALUATION OF THE POLISH CUTTER FISHERY ON THE BALTIC SEA IN THE YEARS 1971-2001. FLEET, CATCH, RESULTS}

$\mathrm{T}$ he objective of the article is to present Polish national fishery on the Baltic Sea in the years 1971-2001. During this period, significant changes of the examined industry occurred, along with its thorough modernisation that ended in practice only in 1992, featured extremely variable fishing results. Finally, the beginning of privatization process in 1989 caused immense marginalisation of fishing, changing its ownership structure for ever. These changes affected mainly national fishing combined collectives and cooperatives that formed peculiar pillars of the national fishing on the Baltic Sea. The first part of article presents issues related to the number of fleet vessels of national businesses and cooperatives, completed modernisations, and it investigates structures of fleets considering averaged power [HP] and buoyancy [GT]. The second part presents issues related to catches. Among the most important factors that have already been analysed are the total volume of raw material acquisition, division of results between combined collectives and cooperatives, share of particular national businesses in catches and averaged results obtained by particular share classes. The last part discusses matters related to averaged fishing results in tones converted into power [HP] and in tones into buoyancy [GT]. An additional supplement is an indication of averaged results per total employment in examined entities, converted into the number of fishermen.

Keywords: baltic fishery, cutters fleet, results, state fleet, cutters. 